DOE/ID/13504

Geothermal Resource/Reservoir Investigations Based on Heat Flow and Thermal Gradient Data for the United States

Final Report - 01/21/1997 - 01/20/2000

D. D. Blackwell

K. W. Wisian

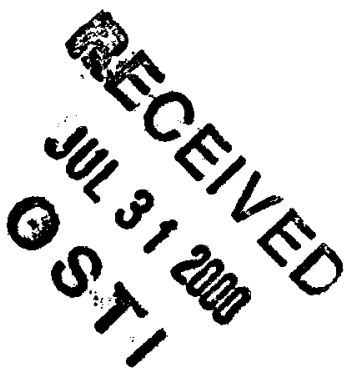

M. C. Richards

J. L. Steele

April 2000

Work Performed Under Contract No. DE-FG07-97ID13504

For

U.S. Department of Energy

Assistant Secretary for

Energy Efficiency and Renewable Energy

Washington, DC

By

Southern Methodist University

Dallas, TX 


\section{DISCLAIMER}

This report was prepared as an account of work sponsored by an agency of the United States Government. Neither the United States Government nor any agency Thereof, nor any of their employees, makes any warranty, express or implied, or assumes any legal liability or responsibility for the accuracy, completeness, or usefulness of any information, apparatus, product, or process disclosed, or represents that its use would not infringe privately owned rights. Reference herein to any specific commercial product, process, or service by trade name, trademark, manufacturer, or otherwise does not necessarily constitute or imply its endorsement, recommendation, or favoring by the United States Government or any agency thereof. The views and opinions of authors expressed herein do not necessarily state or reflect those of the United States Government or any agency thereof. 


\section{DISCLAIMER}

Portions of this document may be illegible in electronic image products. Images are produced from the best available original document. 
DOE/ID/13504

GEOTHERMAL RESOURCE/RESERVOIR INVESTIGATIONS BASED ON HEAT FLOW AND THERMAL GRADIENT DATA FOR THE UNITED STATES

FINAL REPORT

$01 / 21 / 1997-01 / 20 / 2000$

D. D. Blackwell

K. W. Wisian

M. C. Richards

J. L. Steele

April 2000

Work Performed Under Contract No. DE-FG07-97ID13504

Prepared for the

U.S. Department of Energy

Assistant Secretary for

Energy Efficiency and Renewable Energy

Washington, DC

Prepared by

Southern Methodist University

Dallas, TX 
Final Report

\section{GEOTHERMAL RESOURCE/RESERVOIR INVESTIGATIONS BASED ON HEAT FLOW AND THERMAL GRADIENT DATA FOR THE UNITED STATES}

By

David D. Blackwell, Kenneth W. Wisian, Maria C. Richards, and John L. Steele

Department of Geological Sciences, Southern Methodist University, Dallas, Texas, 75275-0395

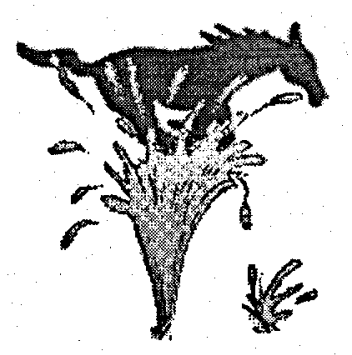

DOE Contract DE-FG07-97ID13504

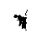

April, 2000 


\section{GEOTHERMAL RESOURCE/RESERVOIR INVESTIGATIONS BASED ON HEAT FLOW AND THERMAL GRADIENT DATA FOR THE UNITED STATES}

\section{Contents}

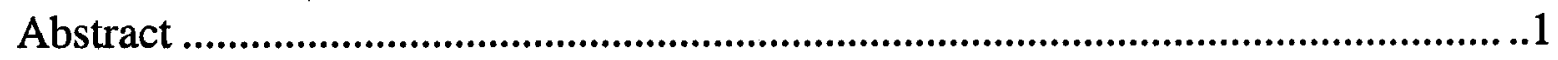

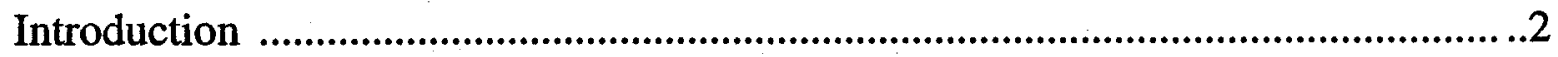

System specific geothermal gradient/heat flow database for the western U.S. .........4

Insights into extensional geothermal systems from numerical modeling .................20

Structure of the Dixie Valley geothermal system from gravity data ........................32

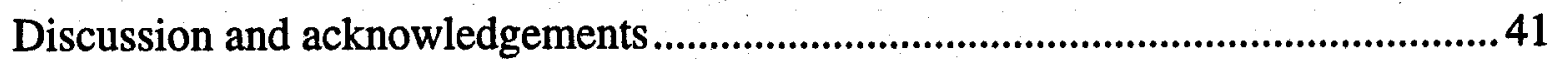

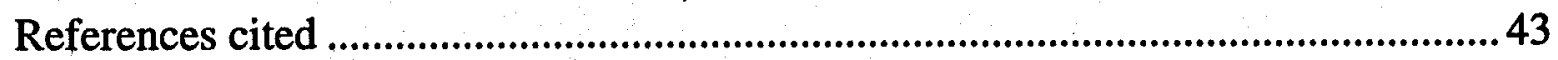




\title{
GEOTHERMAL RESOURCE/RESERVOIR INVESTIGATIONS BASED ON HEAT FLOW AND THERMAL GRADIENT DATA FOR THE UNITED STATES
}

\author{
David D. Blackwell, Kenneth W. Wisian, Maria C. Richards, and John L. Steele \\ Department of Geological Sciences, Southern Methodist Univ., Dallas, TX 75275-0395 \\ http://www.smu.edu/ geothermal
}

\begin{abstract}
Several activities related to geothermal resources in the western United States are described in this report. A database of geothermal site-specific thermal gradient and heat flow results from individual exploration wells in the western U.S. has been assembled. Extensive temperature gradient and heat flow exploration data from the active exploration of the 1970's and 1980's were collected, compiled, and synthesized, emphasizing previously unavailable company data. At the completion of the project the database included over 5300 well sites. Most of these well locations are part of the 133 groups that have been designated as specific geothermal areas. Not all of the wells in each area are anomalous but they have been included in the data set as they can still provide useful information on the regional thermal setting. Another approximately 500 wells are essentially single point sites and may represent potential unexplored geothermal systems. Examples of the use and applications of the database are described. The database and results are available on the world wide web at http://www.smu.edu/ geothermal.
\end{abstract}

One of the more unusual, important geothermal setting in the western U.S. is the Basin and Range province. Unlike the common association of geothermal systems in volcanic areas with magmatism, geothermal systems in the Basin and Range are associated with deep circulation of water along fault and fracture systems in this extensional setting. Magmatic activity plays little part in these systems. The controls on the thermal structure in these systems are not as well understood as in magma systems. This aspect of the report focuses on the characteristics of the Basin and Range province of the United States, but the results apply to extensional settings in general. Understanding these systems is important because most potentially useful geothermal systems remaining in the western U.S., even outside of the Basin and Range, are of the extensional type. In this report numerical models are used to establish basic qualitative relationships between structure, heat input, and permeability distribution, and the resulting geothermal system. A series of steady state, two-dimensional numerical models evaluate the effect of permeability and structural variations on an idealized, generic Basin and Range geothermal system and the results are described here.

An extensional geothermal system only exists in a relatively narrow range of bulk permeability $\left(10^{-15}\right.$ $10^{-16} \mathrm{~m}^{2}$ ). Outside of this window maximum (anomalous) temperature differences in the shallow subsurface decrease rapidly. The presence of a relatively permeable upflow path (provided by geologically recent faulting for example) is a requirement for system development. Chemical selfsealing of upflow paths does not significantly affect the flow system as long as a central flow path is still available. While topography gives an extra, early "kick" to convective circulation, it is not a 
requirement for geothermal system development. A permeable fault in one valley can also induce cross-range flow from adjacent valleys if there are no equally good upflow paths in the adjacent valleys. When bulk permeability is high enough, additional deep circulation cells develop in adjacent valleys diverting heat and fluid from the fault and consequently reducing temperatures in the fault.

The density of high temperature $\left(>150^{\circ} \mathrm{C}\right)$, extensional geothermal systems, increases rapidly with regional heat flow. The fit of the curve suggests that sampling of known geothermal systems is unbiased to any significant degree in all but the highest heat flow regions. Reservoir temperatures (anomalous temperatures) of known geothermal systems are lower in areas with heat flow less than $80 \mathrm{~mW} / \mathrm{m}^{2}$ and generally uninteresting for power generation. For typical values of thermal conductivity, and assuming reservoir temperature equals geochemical system temperature, the depth of circulation of most Basin and Range systems is less than $5 \mathrm{~km}$. Taken together, the data suggest that there is little value to exploration for electric grade resources associated with extensional geothermal systems in areas with a background heat flow of less then $80 \mathrm{~mW} / \mathrm{m}^{2}$.

The Dixie Valley geothermal system, with temperatures up to $248^{\circ} \mathrm{C}$ in the Oxbow field and up to $285^{\circ} \mathrm{C}$ in the Dixie Valley Power Partners leasehold, is the hottest extensional (non-magmatic) geothermal system known in the Basin and Range province. Water circulation to $8-10 \mathrm{~km}$ is probable and thus to near the depth of the brittle ductile transition zone. Thus in areas of active faulting very high temperatures are possible even in the absence of magmatic systems.

The structure of the geothermal system is of particular interest and importance. The structure of the Dixie Valley normal fault system and the role it plays in the associated geothermal system have been debated for some time. The primary structural model has been a single fault with $54^{\circ}$ dip. New data, including reprocessed seismic lines, and temperature-depth results from shallow and deep wells indicate a more complicated structure with a complex zone of fracturing rather than a simple fault structure. In addition to the fault causing the topographic offset, piedmont (within the valley) faults accommodate most of the displacement between the range-valley topographic contact and the bottom of the valley fill. Splays and/or relay ramps are also present. This structure complicates development drilling, but suggests that additional targets for exploration may be present and vastly increases the potential size of the geothermal reservoir associated with this extensional system.

\subsection{INTRODUCTION}

The project was initiated January 20, 1997 and ended January 20, 2000. This project's focus was on geothermal specific heat flow and geothermal gradient data sets in the western United States. This project extended the early geothermal resource evaluations of Muffler (1979), Reed (1983) and Blackwell et al. (1996). The detailed geothermal database developed for the Geological Society of America Decade of North American Geology (DNAG) Geothermal Map of North America (Blackwell and Steele, 1992; Blackwell et al., 1989, 1991) was expanded and updated in a previous project. References to publications of that project are contained in Blackwell et al. (1996). The change to a 
more geographically focused emphasis compared to the previous projects was due to the concentrated nature of the geothermal resource in the high heat flow areas of the western U.S.

The project objectives were to increase the precision and accuracy of geothermal resource estimates and assessments and to regionally characterize geothermal resources in the western United States. These objectives were met by generation of three primary products. First, a database was compiled of previously unavailable company temperature gradient and heat flow exploration data collected during the active geothermal system exploration of the 1970's and 1980's. Second, the database, composed of site specific heat flow, geothermal gradient, and thermal conductivity information for western United States, has been made available to the public for use in resource evaluation and exploration. The primary vehicle is release of the database on the Internet so that it is available for interested parties to download and use directly. Along with this database examples of maps developed from public domain information results in conjunction with data from the compilation that can be used for evaluation and exploration activities are included on the website for illustration purposes. Third, both general and site-specific evaluation models for Basin and Range geothermal systems were developed. The models are designed to aid in estimating the resource potential of a geothermal area thus aiding in the evaluation of current and future exploration sites for geothermal energy.

Each of these objectives is described in this report in separate sections. Section one, "System specific geothermal gradient/heat flow database for the western United States," discusses the details of the database results and summarizes what is available on the Internet site. The second section, "Insights into extensional geothermal systems from numerical modeling," focuses on the Basin and Range. geothermal systems models and implications to other generalized extensional systems. The last section, "Structure of the Dixie Valley geothermal system from gravity data," describes a new model for geothermal systems in the Basin and Range based on data from the Dixie Valley geothermal system in western Nevada, the "classic" Basin and Range geothermal system. 


\subsection{SYSTEM SPECIFIC GEOTHERMAL GRADIENT/HEAT FLOW DATABASE FOR THE WESTERN UNITED STATES}

\subsection{INTRODUCTION}

Background The project described in this report is focused on area specific geothermal gradient and heat flow data sets from geothermal systems in the western United States. The detailed focus is due to the site-specific nature of the geothermal resource in the high heat flow areas of the western U.S. We have previously (Blackwell et al., 1996) expanded and updated the extensive regional geothermal database developed for the Geological Society of America Decade of North American Geology (DNAG) Geothermal Map of North America (Blackwell and Steele, 1992; Blackwell et al., 1989, 1991). The results of that project are described by Blackwell et al. (1994, 1995, and 1996). That project extended the early geothermal resource evaluations of Muffler (1979), and Reed (1983).

Focus This project expands to more complex geothermal conditions in the western Cordillera. As a consequence the types of information for individual wells and thus geothermal systems are greatly expanded. The data for the resource analysis in the western United States have been collected from a variety of published and unpublished sources. A large number of formerly unavailable company temperature gradient and heat flow exploration wells, along with the public domain data available in papers and open-file reports were collected, compiled and synthesized in a standard format. For increased reliability of the data set, a separate verification process was completed on the database using original sources such as well logs and reports to improve accuracy of data.

\subsection{RESEARCH RESULTS}

Western United States Geothermal System Heat flow and Thermal Properties Database This new database is an extension of the "Regional Heat Flow and Thermal Properties Database" of heat flow measurements developed previously (Blackwell et al., 1996). The regional data set consists of approximately 2200 sites throughout the United States containing primarily "regional" or "background" heat flow and other relevant data. Changing the focus of this project from regional conditions for the entire United States, as emphasized previously, to the complex, generally higher heat flow, geothermal conditions in the western Cordillera, greatly increased the amount of well information on geothermal conditions both needed and available. The thermal data from the western United States for this study were collected from a variety of published and unpublished sources. The sources of significant numbers of wells now in the database are: Aminoil USA, AMAX, Anadarko Petroleum, Chevron, Earth Power Production Co., Ensearch, Getty Oil, Gulf, Hunt, NuFuels, Oxy Geothermal, Phillips, Sunoco, Southland Royalty, Transpacific Geothermal, and Union Geothermal. During the active geothermal system exploration of the 1970's and 1980's thousands of holes were drilled for geothermal gradient and heat flow studies. We collected, compiled, and synthesized as much of the company temperature gradient and heat flow exploration data as could be located. In addition, public domain data available in publications and open-file reports were compiled in the same format for completeness and easy access to all well information for a particular geothermal area. 
The state with the most well sites in the new western database is Nevada. During the compilation stage of the data we used the Nevada Bureau of Mines and Geology (NBMG) CD-ROM (Garside, 1997) as an initial starting point. The NBMG database has 2593 well sites. It had not been checked for completeness or accuracy, so of those sites, approximately $57 \%$ of the wells could not be used because the wells were either permitted, but never drilled, were a duplication of another well in that database, or there was no data - only latitude/longitude values and no reference could be found for the data. We used the information from the NBMG CD-ROM when we were able to cross reference it with another source, or if the data was complete. There may be missing well sites in Nevada from the database due to lack of accuracy or data. In the Western U.S. Geothermal database there are 2351 Nevada well sites. There are approximately 1240 Nevada wells not in the NBMG database of 1997, and approximately 1120 sites that overlap the NBMG database. When possible we have added information beyond that in the NBMG database. Of the 1240 additional well sites not in the NBMG database, 1079 wells were drilled by Amax and Phillips.

Database Description: There are two types of wells in the Western U.S. Geothermal System Heat Flow and Thermal Properties Database. The first type are individual thermally anomalous well sites outside any grouping of anomalous wells, identified as geothermal anomalies. These wells are categorized according to the 1:250,000 map where they occur. This is most common in Nevada with the majority of anomalous sites located in the Reno, Lovelock, Millet or Winnemucca 1:250,000 map quadrangles. There are approximately 500 sites of this sort. Many of these are also in the regional data set already developed by Blackwell et al., (1996). However, each of these sites represents a potential geothermal anomaly that has yet to be explored. The second type of database wells are those associated with specific geothermal areas or anomalies (most of the wells) (Figure 1 and Table 1). Wells grouped within a specific geothermal area may have high, low, or regional geothermal gradients and/or heat flow. Within these specific areas we have preferred not to make decisions about the significance of individual wells, this categorization is left as the responsibility of the user. Thus the geothermal area groupings listed generally have wells with essentially regional geothermal gradients along with the high gradient/heat flow wells.

There are 133 geothermal areas with multiple well sets at the present time in the database. These are shown keyed by number on Figure 1 to a corresponding name and location listed in Table 1. To compile the specific geothermal area well site lists, basic information from the multiple sources available to us were combined within a geographic vicinity into a geothermal anomaly area. In most, but not all, cases there was already an established name that could be applied to the area. Also Table 1 and Figure 1 do not represent all the locations of extensive thermal gradient well drilling. There are a number of producing areas represented in the database by only a small number of well sites. The emphasis in this compilation has been on data from areas where exploration and/or evaluation activity might take place in future development of geothermal resources and we have not attempted to include data from many developed systems unless the data were already published. Yellowstone National Park was added to the database and Table 1 because of the unusually large heat loss and high geothermal temperatures near the surface, but it is not considered as a possible future development site. 


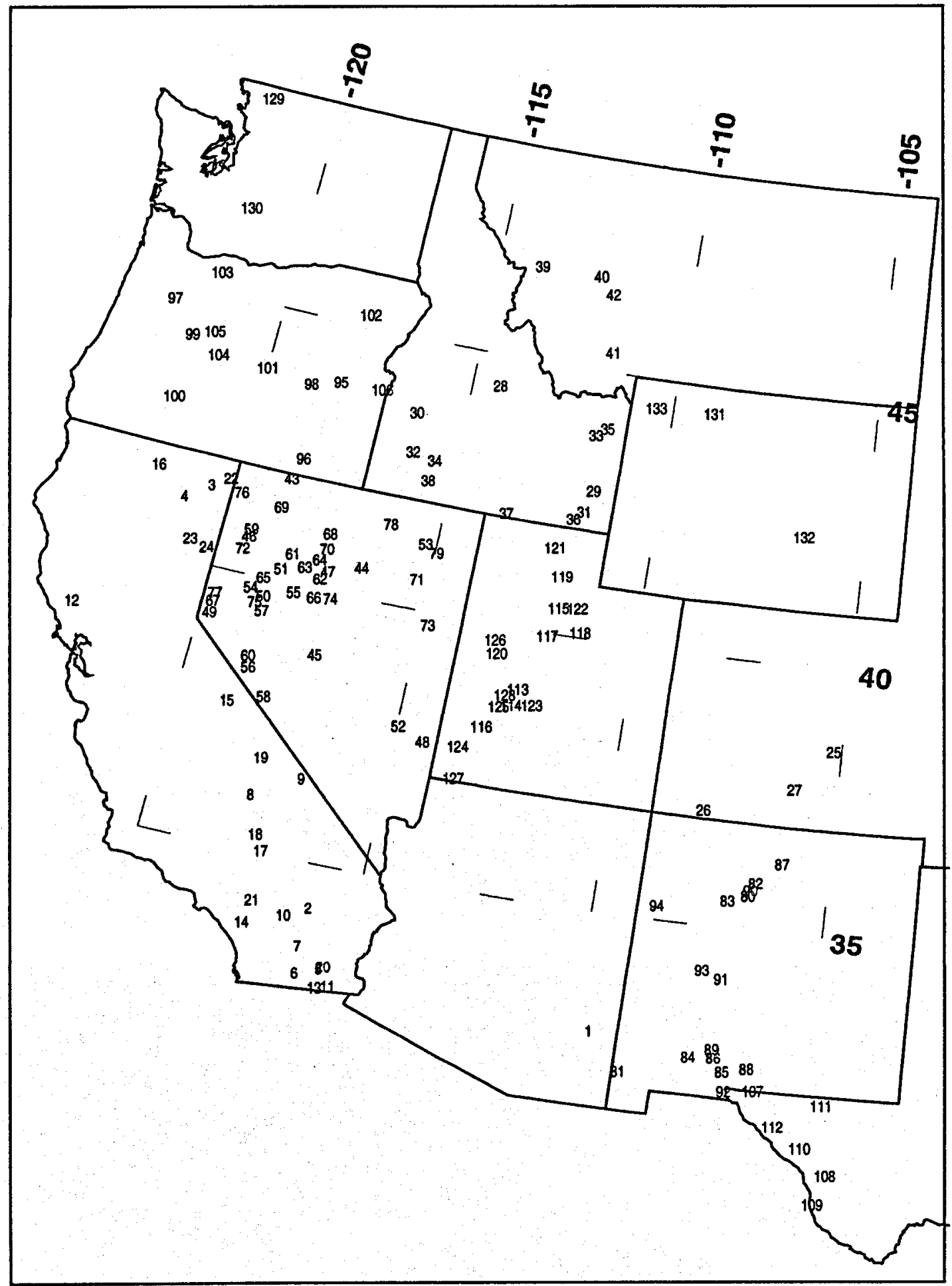

Figure 1. Geothermal areas listed in Table 1. Areas shown have multiple sites within them. Not shown in figure are single well locations. 
Table 1. Western United States geothermal area locations, as shown in Figure 1.

\begin{tabular}{|c|c|c|c|c|c|c|c|}
\hline Geothermal Locations & LAT & LONG & Map \# & Geothermal Locations & LAT & LONG & Map \# \\
\hline Safford Basin, Arizona & 32.75 & -109.67 & 1 & Paradise Valley, Nevada & 41.07 & -117.51 & 68 \\
\hline 29 Palms, Califomia & 34.18 & -116.01 & 2 & Pinto Mountain, Nevada & 41.36 & -118.79 & 69 \\
\hline Alturas Basin, Califomia & 41.47 & -120.53 & 3 & Pumpernickel Valley, Nevada & 40.77 & -117.49 & 70 \\
\hline Beiber, Califomia & 41.15 & -121.06 & 4 & Ruby, Nevada & 40.55 & -115.28 & 71 \\
\hline Brawley, Califomia & 33.08 & -115.50 & 5 & San Emidio, Nevada & 40.45 & -119.41 & 72 \\
\hline Cactus, Califomia & 32.92 & -115.98 & 6 & Shellboume, Nevada & 39.76 & -114.81 & 73 \\
\hline Coachella Valley, Califomia & 33.45 & -116.06 & 7 & Shoshone, Nevada & 39.89 & -117.15 & 74 \\
\hline Coso Hot Spring, Califomia & 36.04 & -117.82 & 8 & Soda Lake - Stillwater, Nevada & 39.54 & -118.83 & 75 \\
\hline Death Valley, Califomia & 36.51 & -116.82 & 8 & Soldier Meadows, Nevada & 41.46 & -119.79 & 76 \\
\hline Desert Hot Springs, California & 33.96 & -116.50 & 10 & Truckee Meadows, Nevada & 39.53 & -119.76 & $\pi$ \\
\hline East Mesa, Califomla & 32.79 & -115.23 & 11 & Tuscarora, Nevada & 41.47 & -116.17 & 78 \\
\hline Geysers-Clearlake, Califomia & 38.75 & -122.83 & 12 & Wells, Nevada & 41.11 & -114.97 & 79 \\
\hline Heber, Califomia & 32.72 . & -115.50 & 13 & Albuquerque, New Mexico & 35.65 & -106.70 & 80 \\
\hline Lake Elsinore, Califomia & 33.68 & -117.33 & 14 & Animas, New Mexico & 32.07 & -108.93 & 81 \\
\hline Long Valley, Califomia & 37.65 & -118.86 & 15 & Baca - Valles Area, New Mexico & 35.89 & -106.57 & 82 \\
\hline Medicine Lake-Glass Mtn., CA & 41.61 & -121.85 & 16 & Cabezon, New Mexico & 35.52 & -107.13 & 83 \\
\hline Mojave Desert, Califomia & 35.05 & -117.30 & 17 & Florida, Now Mexico & 32.50 & -107.52 & 84 \\
\hline Randsburg, Calilomia & 35.33 & -117.50 & 18 & Las Alturas, New Mexico & 32.29 & -106.78 & 85 \\
\hline Saline Valley, Calilomia & 36.75 & -117.80 & 19 & Las Cruces, New Mexico & 32.53 & -107.00 & 86 \\
\hline Salton Sea, Calitomia & 33.13 & -115.41 & 20. & Ojo Caliente Wam Springs, NM & 36.30 & -106.04 & 87 \\
\hline San Bemardino-Hartem HS, CA & 34.12 & -117.23 & 21 & Otero County, New Mexico & 32.39 & -106.28 & 88 \\
\hline Surprise, Califomia & 41.67 & -120.12 & 22 & Rio Grande Rift, Now Mexico & 32.68 & -107.05 & 89 \\
\hline Susanville, Califomia & 40.41 & -120.65 & 23 & San Diego Grant, New Mexico & 35.75 & -106.66 & 90 \\
\hline Wendel-Amedee- Honey Lake, CA & 40.32 & -120.23 & 24 & Socorro, New Mexico & 34.02 & -107.04 & 91 \\
\hline Canon City, Colorado & 38.48 & -105.19 & 25 & Strauss, New Mexico & 31.92 & -106.70 & 92 \\
\hline Durango, Colorado & 37.15 & -107.92 & 26 & Tres Montosas, New Mexico & 34.15 & -107.48 & 93 \\
\hline San Luis Valley, Colorado & 37.70 & -105.96 & 27. & Zunt, New Mexicó & 35.27 & -108.63 & 94 \\
\hline Bayhorse, Idaho & 44.40 & -114.32 & 28 & Beulah, Oregon & 43.88 & -118.17 & 95 \\
\hline Blackłoot, Idaho & 42.75 & -111.60 & 29 & Borax Lake - Alvord Valley, Oregon & 42.33 & -118.58 & 96 \\
\hline Boise, Idaho & 43.62 & -116.18 & 30 & Breitenbush, Oregon & 44.67 & -122.67 & 97 \\
\hline Franklin County - Maple Grove, Idaho & 42.33 & -111.73 & 31 & Bums, Oregon & 43.72 & -118.86 & 98 \\
\hline Grandview, ldaho & 42.88 & -116.06 & 32 & Cascades, Oregon & 44.10 & -122.00 & 99 \\
\hline Madison County, Idaho & 43.79 & -111.78 & 33 & Crater Lake, Oregon & 42.90 & -121.89 & 100 \\
\hline Magic Reservoir - Snake Rv. Plains, Idaho & 42.80 & -115.50 & 34. & Glass Butte, Oregon & 43.83 & -120.00 & 101 \\
\hline Newdale, Idaho & 43.94 & -111.53 & 35 & La Grande, Oregon & 45.22 & -117.87 & 102 \\
\hline Preston - Bear River Prospect, idaho & 42.17 & -111.95 & 36 & Mount Hood, Oregon & 45.35 & -121.75 & 103 \\
\hline Raft River, Idaho & 42.08 & -113.55 & 37. & Newberry, Oregon & 43.85 & -121.25 & 104 \\
\hline Twin Falls and Jerome Counties, Idaho & 42.41 & -115.55 & 38 & Santiam Pass, Oregon & 44.25 & -121.50 & 105 \\
\hline Deer Lodge, Montana & 46.75 & -113.90 & 39 & Vale, Oregon & 43.90 & -117.14 & 106 \\
\hline Marysville, Montana & 46.75 & -112.37 & 40 & Hueco Tanks, Trans-Pecos, Texas & 31.99 & -106.10 & 107 \\
\hline Texton - Ennis Geothermal Area, NT & 45.37 & -111.73 & 41. & Marfa, Texas & 30.54 & -104.44 & 108 \\
\hline White Sulfur Springs, Montana & 46.45 & -111.99 & 42 & Presidio Boisum, Texas & 29.97 & -104.65 & 109 \\
\hline Baltazor and McGee, Nevada & 41.92 & -118.73 & 43 & Alo Grande Valley, Texas & 31.00 & .105 .02 & 110 \\
\hline Beowawe, Nevada & 40.56 & -116.60 & 44 & Sall Basin, Toxas & 31.83 & -104.66 & 111 \\
\hline Big Smokey Valley Area, Nevada & 38.81 & -117.19 & 45 & Van Hom, Texas & 31.36 & $\cdot 105.62$ & 112 \\
\hline Black Rock Desent, Nevada & 40.70 & -119.35 & 46 & Best, Utah & 38.88 & .112 .49 & 113 \\
\hline Buena Vista Valley, Nevada & 40.36 & -117.35 & 47 & Cove Fort Sulphurdale, Utah & 38.57 & -112.57 & 114 \\
\hline Caliente, Nevada & 37.62 & -114.37 & 48 & Crystal Hot Springs, Utah & 40.49 & -111.91 & 115 \\
\hline Carson - Eaglo Valley, Nevada & 39.16 & -119.77 & 49 & Escalante Desert, Utah & 38.09 & -113.14 & 116 \\
\hline Carson Sink, Nevada & 39.67 & -118.67 & 50 & Eureka, Utah & 39.95 & -112.05 & 117 \\
\hline Colado, Nevada & 40.24 & -118.43 & 51 & Fifth Water, Utah & 40.10 & -111.31 & 118 \\
\hline Coyote Springs, Nevada & 37.83 & -114.97 & 52 & Hill Air Force Base, Utah & 41.08 & -111.96 & 119 \\
\hline Deeth, Nevada & 41.23 & -115.27 & 53 & Little Drum - Keg Mountains, Utah & 39.48 & .113 .13 & 120 \\
\hline Desert Peak-Brady Hot Springs, Nevada & 39.78 & -119.00 & 54 & Lttle Mountain, Utah & 41.59 & -112.25 & 121 \\
\hline Dixie Valley, Nevada. & 39.86 & -118.01 & 55 & Midway, Utah & 40.53 & -111.47 & 122 \\
\hline Excelslor, Nevada & 38.33 & -118.59 & 56 & Monroe-Red Hill, Utah & 38.63 & -112.11 & 123 \\
\hline Fallon NAS - Carson Lake, Nevada & $39.41:$ & -118.62 & 57 & Newcastle, Utah & 37.66 & -113.57 & 124 \\
\hline Fish Lake -Alum - Emigrant, Nevada & 37.86 & -118.08 & 58 & Roosevelt Hot Springs, Utah & 38.51 & -112.84 & 125 \\
\hline Fly Ranch, Hualapai Flat and Gerlach, NV & 40.83 & -119.33 & 59 & Spor Mountain, Utah & 39.72 & -113.22 & 126 \\
\hline Hawthome, Nevada & 38.54 & -118.66 & 60 & St. George Basin, Utah & 37.05 & -113.53 & 127 \\
\hline Humboldt House - Rye Patch, Nevada & 40.55 & -118.25 & 61 & Twin Peaks, Utah & 38.74 & : -112.75 & 128 \\
\hline Jersey Valley, Nevada & 40.20 & -117.48 & 82 & Baker Mountain, Washington & 48.76 & -121.81 & 129 \\
\hline Kyle Hot Springs - Granite Mountain, NV & 40.36 & -117.90 & 63 & Ohanapecosh, Washington & 46.66 & -121.51 & 130 \\
\hline Loach Hot Springs-Grass Valley, Novada & 40.55 & -117.61 & 64 & Cody, Wyoming & 44.50 & -109.00 & 131 \\
\hline MacFarlane Hot Springs, Nevada & 40.01 & -118.77 & 65 & Laramie, Hanna \& Shirley Basins, WY & 42.40 & -106.45 & 132 \\
\hline McCoy, Nevada & 39.85 & -117.53 & 66 & Yellowstone National Park, Wyoming & 44.46 & -110.44 & 133 \\
\hline
\end{tabular}


The Western United States Geothermal System Heat Flow and Thermal Properties Database has been designed to contain numerous parameters of possible use in exploration and evaluation activities. The ideal set of information for each geothermal gradient/heat flow exploration site in the database would include:

a) LOCATION: GEOTHERMAL AREA, HOLE NAME, TECTONIC PROVINCE, LATITUDE, LONGITUDE, TWN/RNG-SEC,

b) THERMAL MEASUREMENTS: CORRECTED \& UNCORRECTED GRADIENT, HEAT FLOW, THERMAL CONDUCTIVITY, QUALITY OF DATA, MAXIMUM \& BOTTOM HOLE TEMPERATURE,

c) WELL SITE PARAMETERS: LITHOLOGY INFORMATION, DRILL \& LOG DATES, COLLAR ELEVATION, DRILL DEPTH, WATER TABLE DEPTH,

d) REFERENCE(S): SOURCE(S )OF ORIGINAL DATA \& COMMENTS.

In addition ideally there are available detailed equilibrium temperature-depth data, a large scale location map, and a detailed lithologic log for each well in the data base. Of course in reality the original data may have been lost or may not have been released and so for many wells the information listed is not all available. In fact for some wells only a location and a geothermal gradient are included in the database and these parameters represent the sum total of the information available to us. Even this limited information is very useful in site specific evaluation activities, however.

Table 2 shows the individual state break down in the availability and types of data. There are more gradients in some states than actual wells. This is because there are multiple gradient intervals for some of the wells. When the temperature-depth data were available and nonlinear temperature depth curves were obvious, then multiple thermal gradient intervals were included in the database.

There were over 5300 sites in 12 western states in the database at the end of the project. The data available for each well ranges from extensive to as little as a location and a geothermal gradient, so complete comparisons of the results are difficult. Other related parameters available in over a third of the well sets are bottom hole temperatures, heat flow and thermal conductivity. A series of histograms (Figure 2a,b,c,d) are presented to give a general overview of the database information. The histogram of the well depths is shown in Figure 2a. Most of the wells are less than $200 \mathrm{~m}$ (700 ft) in depth, as thermal gradient exploration wells have been the focus of the compilation. However, 114 wells are

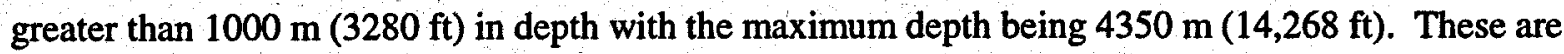
generally wells drilled as production exploration wells with results available in the literature. 
Table 2. Primary parameters in the Western U.S. Geothermal database on a state to state basis.

\begin{tabular}{lccccc}
\hline State & $\begin{array}{c}\text { Number of } \\
\text { wells in } \\
\text { database }\end{array}$ & $\begin{array}{c}\text { Number of } \\
\text { BHT's in } \\
\text { database }\end{array}$ & $\begin{array}{c}\text { Number of } \\
\text { gradient } \\
\text { points }\end{array}$ & $\begin{array}{c}\text { Number of } \\
\text { heat flow } \\
\text { points }\end{array}$ & $\begin{array}{c}\text { Number of } \\
\text { conductivity } \\
\text { points }\end{array}$ \\
\hline Arizona & 31 & 10 & 31 & 29 & 18 \\
California & 795 & 155 & 786 & 439 & 418 \\
Colorado & 46 & 26 & 45 & 46 & 45 \\
\hline Idaho & 326 & 257 & 315 & 208 & 184 \\
Montana & 105 & 84 & 105 & 31 & 31 \\
New Mexico & 541 & 349 & 540 & 295 & 280 \\
\hline Nevada & 2191 & 990 & 2202 & 471 & 469 \\
Oregon & 392 & 193 & 389 & 324 & 327 \\
Texas & 323 & 113 & 330 & 17 & 17 \\
\hline Utah & 562 & 501 & 562 & 404 & 402 \\
Washington & 12 & 3 & 12 & 4 & 4 \\
Wyoming & 57 & 25 & 57 & 40 & 40 \\
\hline
\end{tabular}
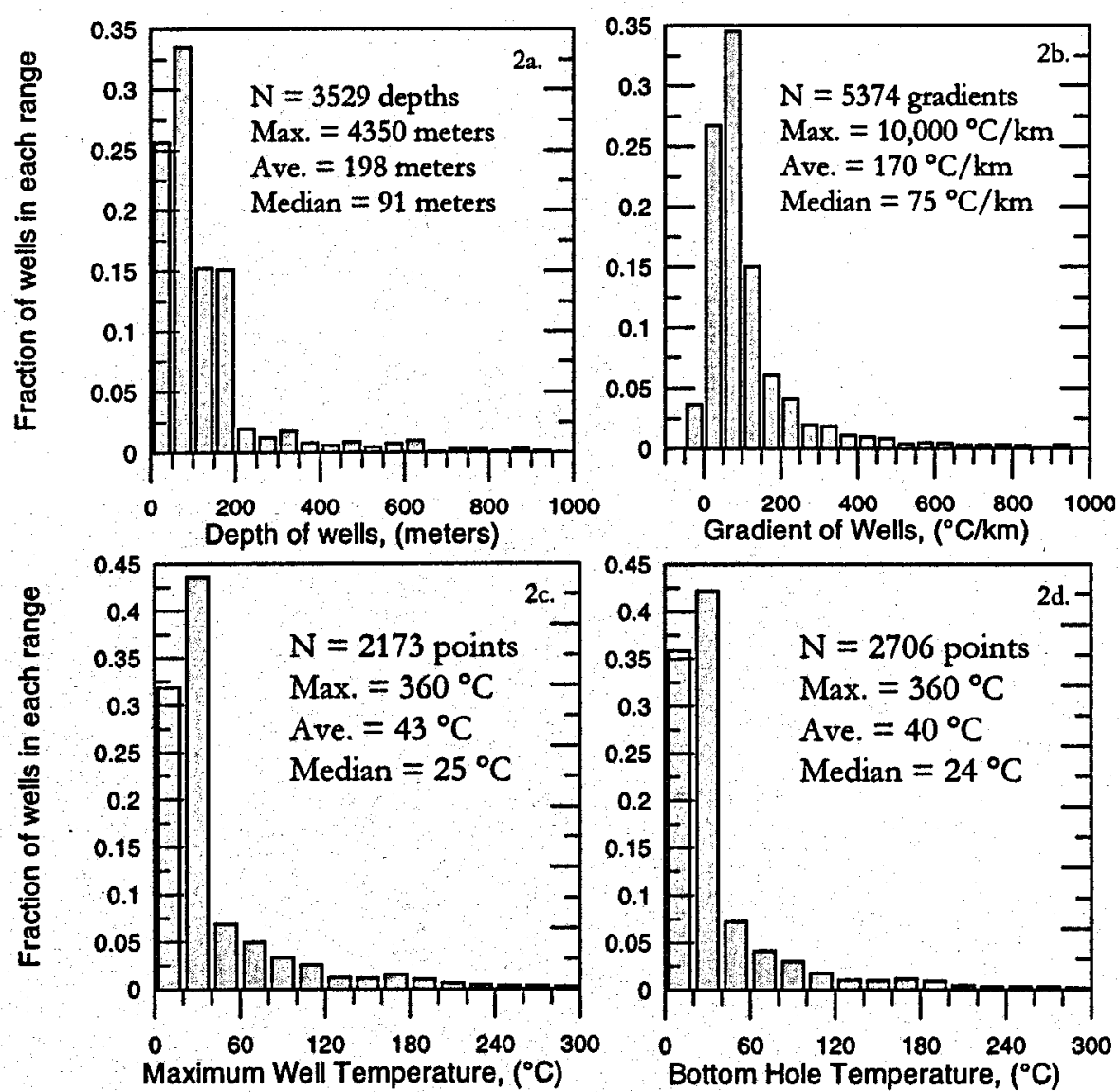

Figures $2 a, 2 b, 2 c$ and $2 d$. Database well information in categories showing the number of individual sites within the category ranges versus the total number of locations. 
Probably the single most important parameter in the database is the gradient value for each well. Therefore if temperature-depth data were available for a well as much detail is included on the variations of gradient with depth as possible. Since most reports available to us contained plotted gradients and/or had temperature-depth data, in depth examination of gradient variations was possible. Thus one parameter that can be investigated using the database is how gradients change with depth. A histogram of the "uncorrected" geothermal gradient(s) for the 4621 wells with gradient information is shown in Figure 2b. The median value for geothermal gradient is $73^{\circ} \mathrm{C} / \mathrm{km}$ while the average is 158 ${ }^{\circ} \mathrm{C} / \mathrm{km}$. There are 96 wells with an average gradient of over $1000^{\circ} \mathrm{C} / \mathrm{km}$ and a maximum gradient of $10,000{ }^{\circ} \mathrm{C} / \mathrm{km}$. The vicinity of Yellowstone National Park has the highest gradients because of the extreme near surface temperatures. The total number of gradients is more than the total number of well locations because many of the wells have more than one gradient value. There are 527 wells with two or more gradient intervals, 122 wells with three or more gradient intervals, and 32 wells with four or more gradient intervals. An observation based on gradients is that the higher the gradient value the more shallow the depth to the geothermal anomaly causing that high gradient. Figure $4 \mathrm{a}$ also shows this feature of high gradient values with shallow depths and lower gradient values with deeper depths. For future exploration this is an important point to emphasize, the higher the geothermal gradient the shallower the source of the anomaly is likely to be.

Data were also obtained for bottom hole temperature (BHT) and maximum well temperature (Figures 2c- 2d). There are 2513 wells with temperatures less than $100^{\circ} \mathrm{C}\left(212^{\circ} \mathrm{F}\right)$ and 193 wells over $100^{\circ} \mathrm{C}$. If only the well summary information was available it was more common to find BHT than maximum well temperature. When maximum temperature is listed in the database for a well it was obtained from either a report summary, or a temperature well log. It was not assumed that the BHT was also the maximum temperature. In geothermal areas, many of the hottest temperatures are closer to the surface and not the bottom of the well. The average BHT of the wells from the western 12 states (Figure 1), is as follows: $\quad$ Arizona $-29{ }^{\circ} \mathrm{C}, \quad$ California $-52{ }^{\circ} \mathrm{C}, \quad$ Colorado $-16{ }^{\circ} \mathrm{C}$ Idaho -34 ${ }^{\circ} \mathrm{C}$,Montana $-33^{\circ} \mathrm{C}$ New Mexico $-43^{\circ} \mathrm{C}$, Nevada $-43^{\circ} \mathrm{C}$, Oregon $-41^{\circ} \mathrm{C}, \quad$ Texas $-27^{\circ} \mathrm{C}, \quad$ Utah $-35^{\circ} \mathrm{C}, \quad$ Washington $-30^{\circ} \mathrm{C}$, Wyoming $108^{\circ} \mathrm{C}$ (with Yellowstone National Park, $34^{\circ} \mathrm{C}$ without it). Generally the BHT and the maximum temperature are the same as the histograms show (Figures $2 \mathrm{c}-2 \mathrm{~d}$ ). According to Gass (1982) average shallow ground temperatures vary from about $4.4^{\circ} \mathrm{C}\left(40^{\circ} \mathrm{F}\right)$ in the northern U.S. to about $26.6^{\circ} \mathrm{C}\left(80^{\circ} \mathrm{F}\right)$ in the southern United States (Figure 3).

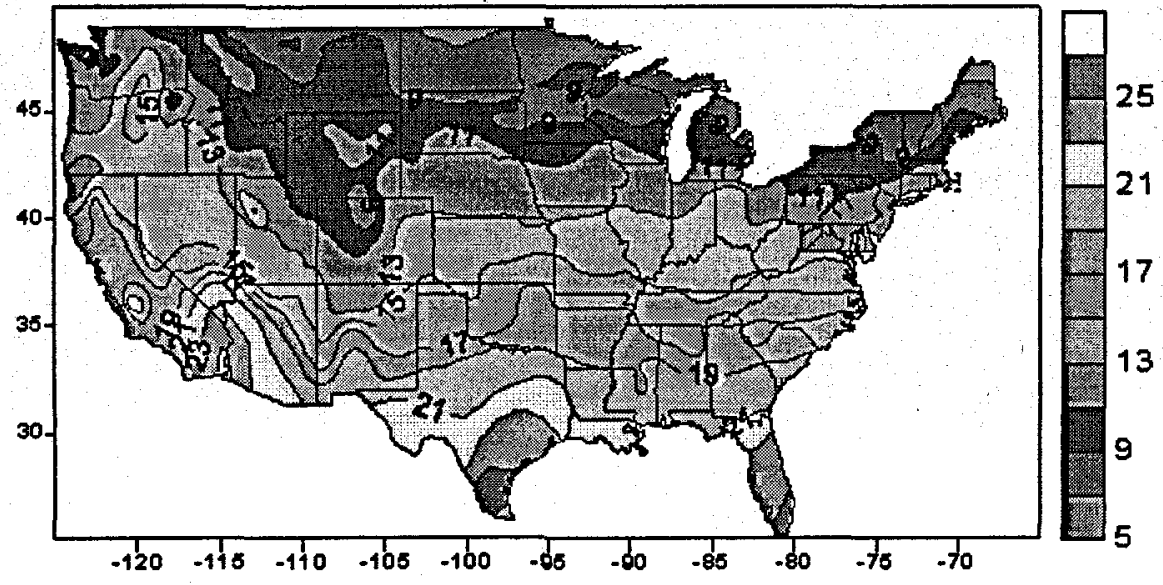

Figure 3. Average shallow groundwater temperatures (Gass, 1982). 
A comparison of the depth(s) of all the database wells versus gradient, conductivity and heat flow is shown in Figures $4 a, 4 b$, and $4 c$. This was done using the deepest depth range for each well gradient, heat flow and conductivity value when multiple intervals were available. The gradient and heat flow graphs follow a similar spatial distribution. The thermal conductivity values are not as similar to the others as might be expected (Figure $4 \mathrm{~b}$ ). For this database the thermal conductivity is usually the average for the entire depth range and not gradient specific, which helps explain the spatial variances of the conductivity data. To determine heat flow the gradient is multiplied by the thermal conductivity. Not all gradients have heat flow values associated with them because of lack of interval specific thermal conductivity values. When the data were reviewed for accuracy, the gradient and heat flow plots were one method used to look for data inconsistencies.
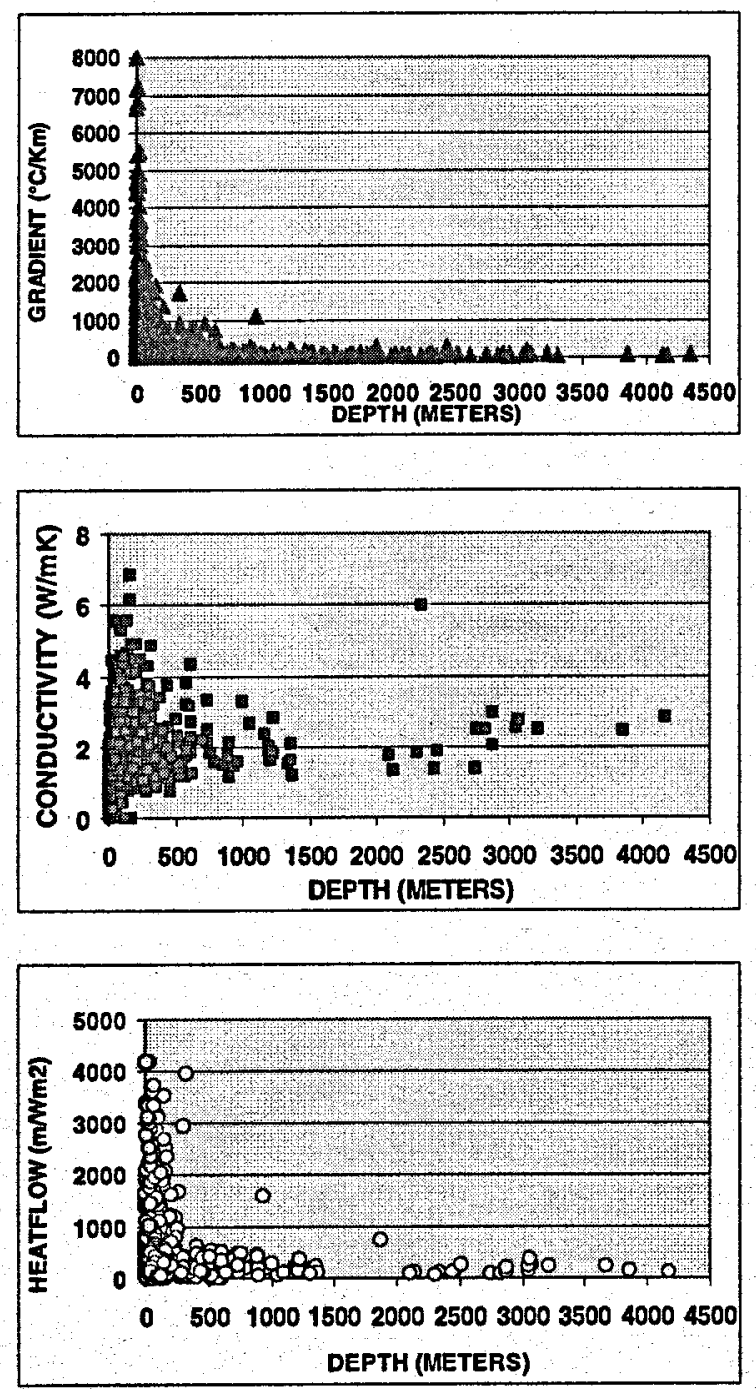

Figure 4a. All database maximum depths versus the gradient value. For wells with more than one gradient interval the depth plotted on this graph is the maximum depth corresponding to that gradient interval.

Figure 4b. Database thermal conductivity versus maximum depth. The average number of samples per value is 8 samples.

Figure 4c. Database heat flow versus maximum depth. When there was more than one heat flow value for a well then the corres-ponding maximum depth for each value was used. 
Web Page Data A major part of the dissemination of the results from this three year contract is the availability of the data in spread sheet format and downloadable from the home page on the Internet at www.smu.edu/ geothermal (Figure 5). The web site is designed for a user-friendly open dialog between the Southern Methodist University Geothermal Laboratory and interested persons in the geothermal field. There are three main components of the web site. First is the Heat Flow page that contains the regional heat flow database (Heat Flow link). It has maps of the conterminous United States heat flow and related maps from the previous DOE Contract (Blackwell et al., 1996). There are also reference materials listed. The second page is the Geothermal Resources page. This Geothermal Resources link is directly related to the Western United States geothermal database discussed in this report. Individual states can be accessed or the entire database, references and maps are downloadable in a Microsoft Office format and in a general text format (Figure 6). See the Resource Analysis section below for more details on examples from the Geothermal Resources page (Figures 7-9). The third page is the Temperature Log page with examples of temperature-depth curves (over 70 curves shown) and a brief tutorial on how to interpret temperature-depth curves (Temperature Logs link). Links to publications related to well logging are also available from this page.

Resource Analysis As an example of how the data sets can be used for an individual geothermal area description, data from McCoy, geothermal area in Churchill County, Nevada (Olson et al., 1979, Pilkington, 1982, AMAX, 1980, 1981a, 1981b, 1981c) were analyzed and graphic summaries prepared (Figure 7a-b). The thermal gradient contours from the compiled data set are overlaid on a scanned version of the county geologic maps (Willden and Speed, 1974; Stewart and McKee, 1977). Overlays with topography are also possible due to the availability of digital data sets at 1:250,000 and 1:24,000 scales from the U.S. Geological Survey (http://edcwww.cr.usgs.gov/doc/edchome/ndcdb/ndcdb.html). The data locations are divided into shallow $(<150 \mathrm{~m})$ and deep $(>150 \mathrm{~m})$ well depths. The deep well sites are usually determined using shallow hole data and geology structure to locate the apex of the geothermal anomaly. By using the different depths of well gradients, the data user can study changes from the surface to deeper layers or do a combined thermal map as shown in Figure 7a. On the web site there are additional examples of how the data can be used to produce contour maps to better understand individual Nevada geothermal systems. The areas depicted as examples are: Black Rock Desert, McCoy, Desert Peak, Brady Hot Springs, Gerlach, Fly Ranch and Grass Valley. An example of how we generated the maps is available on the same page (Figure 8). We have had numerous requests for the contour maps on the web site and we can give that information out per request in both grid and $x, y, z$, formatting.

Hard copies of data from geothermal areas listed in Table 1 are available upon request when the data on the Internet are not sufficient. The online reference lists may be used to determine what material is needed. One item about which the Southern Methodist University Geothermal Lab generally has more data available than what is shown on the internet is lithology. Where lithology is given, the information has been often generalized from more detailed original well logs. 


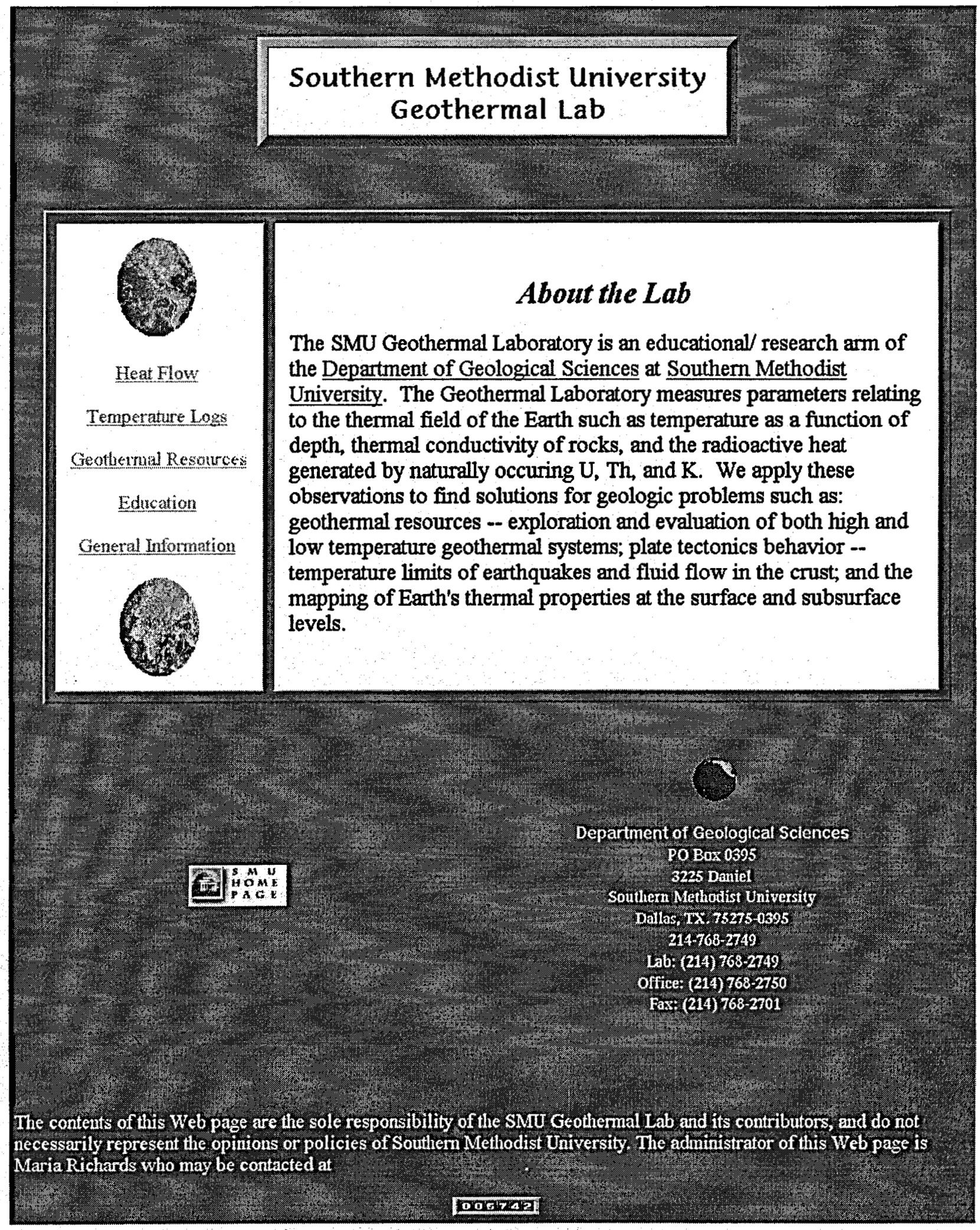

Figure 5. Home page of Southern Methodist University Geothermal Laboratory. 
REGIONAL HEAT FLOW DATA BASE

Nevada89.csv - Data base points for Nevada up to 1989.

Nevad96.csv - Updates for Nevada data base since 1989:

Manual for data base with parameter description, Microsoft Word 6.0 format, or Manualin *.txt format.

Reference list for data base, Microsoft Word 6.0 format, or Reference in text format.

\section{WESTERN GEOTHERMAL AREA DATA BASE}

NV99.xls and NV99.csv - the Nevada data base wells in two different formats.

README file for specific information about this data base.

Reference list for data base in glphahetical order or by Geothermal areas, Microsoft Word 6.0;

*.txt format - glphabetical order or Geothermal areas

Wyou are aware of more recent data for this area or older dato that are wetssing, please let ws know.

Disclainer: the well information in the two data bases has been checked for accuracy to the best of our ability. The data came from many sources and some wells have different values for the given information. When this occurs we often left in both values. With a data base this size there will always be more corrections and hope that if you discover wells that need to be corrected that you will pass this information on to Maria Richards. We would also recommend that you let us know that you are using the data base, that way we can let you know about any future corrections.

Thank you. mrichard@mail.smu.edu.

return to USA map

Figure 6. One example of state specific accesses to the geothermal database on the web site. 

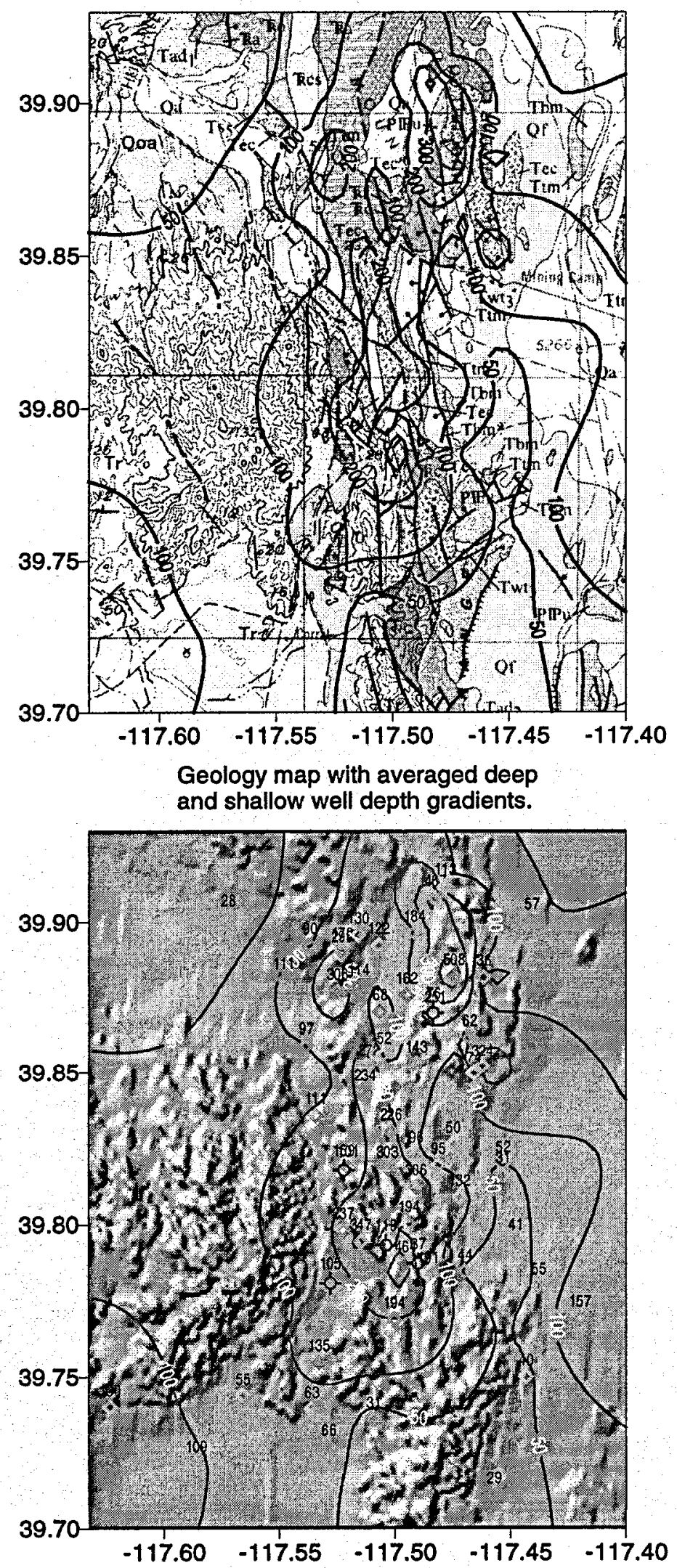

Topography map, gradients (deep, $\$$, and shallow, $\diamond)$ and well locations with gradient values $\left({ }^{\circ} \mathrm{C} / \mathrm{km}\right)$.
Figure 7a. McCoy, Nevada, geothermal area.

Figure 7b. McCoy, Nevada, geothermal area. 


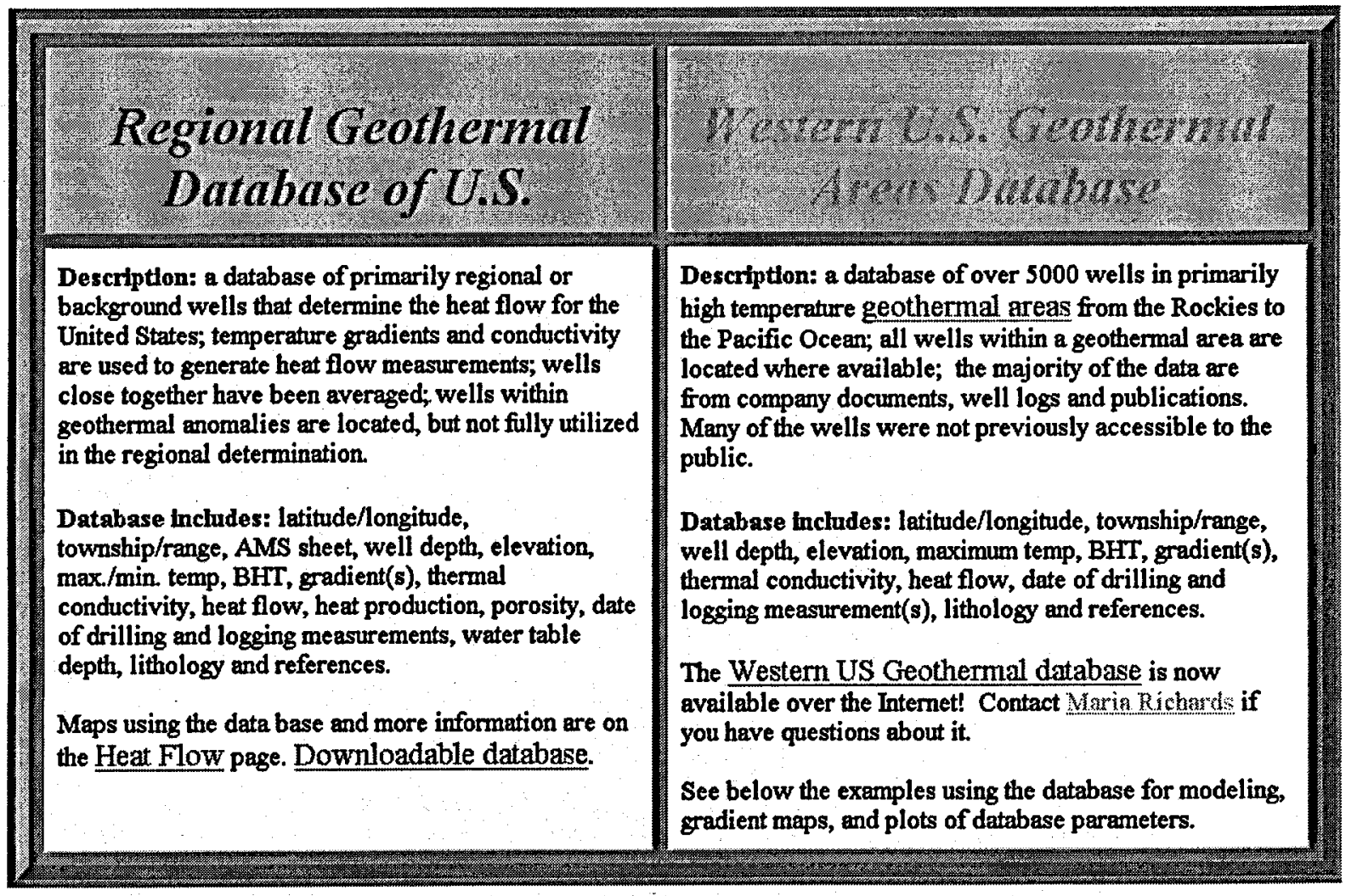

The western United States has multiple areas where high and low temperature geothermal energy is available. Both temperature types are being used for small and large scale energy production in many of the Western states. The following examples of Geothermal Areas are shown to give ideas of what is possible with the Western Geothermal Area Database. The geothermal areas represented are Desert Peak, Brady Hot Springs, Black Rock Desert, Gerlach, Fly Ranch, McCoy, Leach Hot Springs, and Grass Valley. The gradient maps were produced using the gradient data (at multiple depths to view possible over-turns in the gradient) and the program Surfer by Golden Sofuware. The geology maps were scanned from the Nevada Bureau of Mines Bulletins. The surface topography maps are from the U.S.G.S. GtoData homepage, specifically the $1: 250,000$ maps. There are now available from the U.S.G.S. digital maps at a scale of 1:24,000. The images below can be saved for more detailed viewing. In examining the gradients, we have displayed the gradient contours for the "deep", "shallow" and "combined" well depths. Deep gradients are usually 150 meters and deeper. In general there are many more well gradients for shallow depths than deep. A deep well location could have both a deep and shallow gradient if the gradient changed over the depth intervals. This offen occurs when the well gradient is high in the shallow depths and then becomes isothermal or negative for the deeper gradient interval. The gradient maps below have not been limited to the aerial extent of the actual well locations. The areas of gridding away from the well locations do not necessarily depict the proper gradient values for these areas.

The next step for understanding the data is to include the temperature-depth curves for the wells examined. In order to determine a well's thermal significance, the well temperature-depth curve is studied in comparison to regional and local conditions. A series of example temperature-depth curves with descriptions of the factors that effect their character are found at the Temperature Log page. Any discussion the following graphics develop is welcome.

Figure 8. Geothermal Resources web page header and a description of the database and methods for generating figures similar to Figures $7 \mathrm{a}-\mathrm{b}$ are found on this page. 


\subsection{MODELING OF EXTENSIONAL GEOTHERMAL SYSTEMS; THE BASIN AND RANGE}

In addition to compiling the western United States geothermal database, a resource analysis has been in progress. A modeling study of the Basin and Range as examples of extensional geothermal systems was initiated using heat flow and gradient from the database and then applying fault data. While it has been recognized that there are frequent associations of geothermal systems in the Basin and Range with faulting, the degree of correlation was qualitative. Merging the geothermal well database with a compilation of geologically recent faulting (Raines et al., 1996) shows the degree of correlation between the two. Combining the two databases shows that $90 \%$ or more of major known geothermal systems are within $3 \mathrm{~km}$ of late Pleistocene or younger faults (Figure 9). This correlation suggests that future exploration in the region should include young faults as a key indicator. One of the better examples of the close association of historic faulting and geothermal systems is Dixie Valley, Nevada where there is geothermal production immediately to the north of a 1954 surface rupture zone (Bell and Katzer, 1987). The close association between recent faulting and the existence of geothermal systems suggests that recent faulting is a requirement for system development (due to the effect of self-sealing) and that future exploration in the region should include young faults as a key indicator. Over $95 \%$ of the geothermal systems with temperatures over $150^{\circ} \mathrm{C}$ occur in areas where the regional heat flow is greater than $80 \mathrm{mWm}^{-2}$. This result can be attributed to two factors. Young magma chambers will be found in areas with high regional heat flow as high temperature conditions are required at depth to generate magmas. Secondly, for geothermal systems related to deep circulation of water rather than localized magma systems, there seems to be a "maximum" depth of circulation of about $6 \mathrm{~km}$. Thus the higher the heat flow in an area, the higher will be the temperature experienced by the deeply circulating water. Clearly background heat flow is one factor in evaluating regional potential for high temperature geothermal systems. Taken together, the data suggest that there is little value to explore for extensional geothermal systems in areas with less then $80 \mathrm{~mW} / \mathrm{m}^{2}$ background heat flow (Wisian et al., 1999a). More on the details of the modeling are discussed in the following section.

\subsection{INDUSTRY INTEREST AND TECHNOLOGY TRANSFER}

We have had an increasing number of inquires from Internet contacts and conventional contacts for information on temperatures and geothermal gradients. The list in Table 3 shows examples of organizations that have requested information and extent of interest related to the web site. The breadth of interest in this type of information can be gauged from the large variety of requests. We currently have approximately three to four requests per month for information. For every organization request we receive there are about two individual requests. 


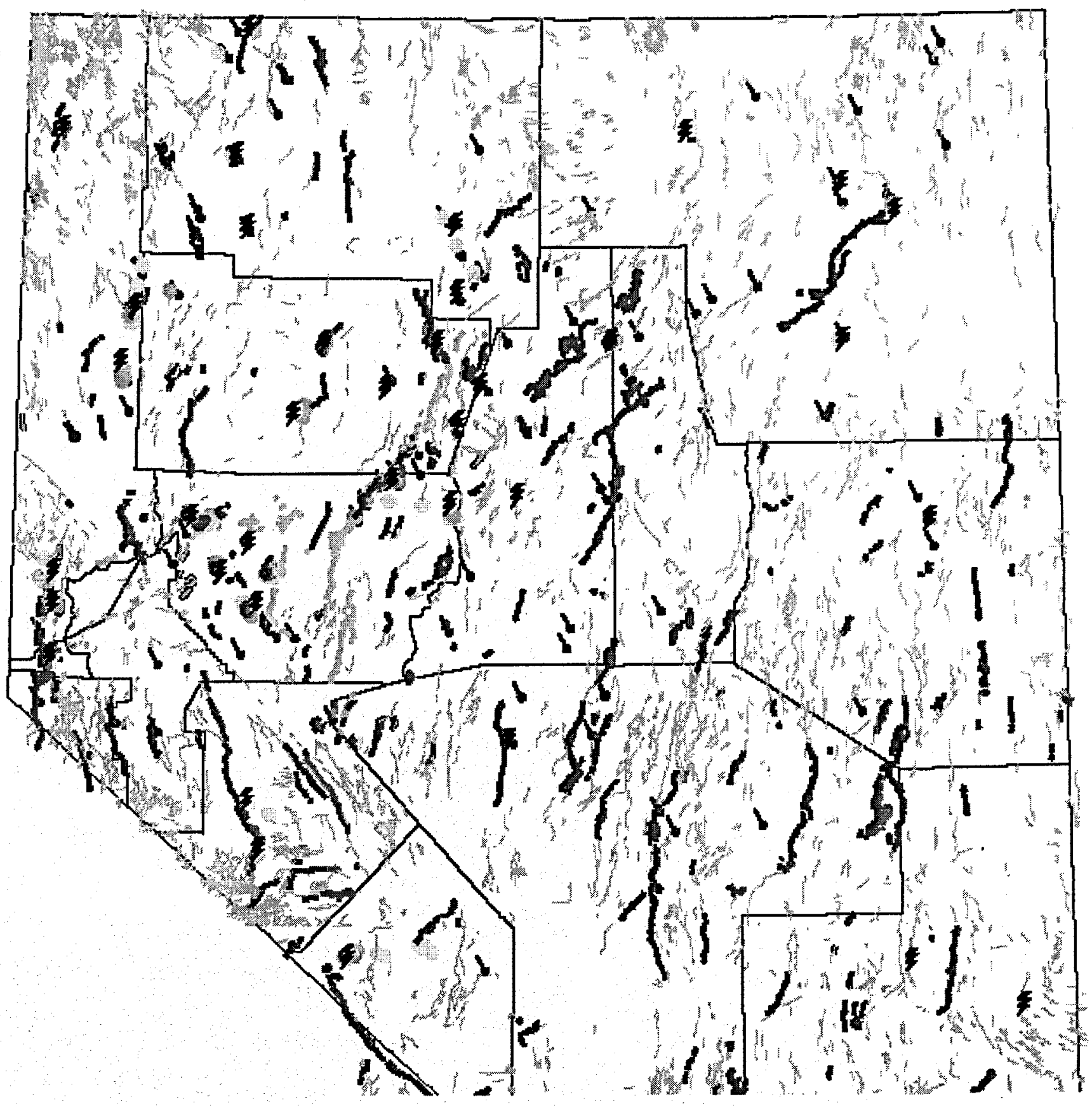

Figure 9. Correlation of the geothermal systems to geologically recent faulting. The faults are shown as lines of varying thickness and color. The pink faults are undated. The lighter green the line the younger the fault, starting with Historic and the darkest green lines represent Late Pleistocene faults. Circles represent gradients: red $=$ highest gradient and yellow = lowest gradients. Geothermal springs are represented by a dot with a tail (blue color). 
Table 3. Examples of groups interested in the geothermal database.

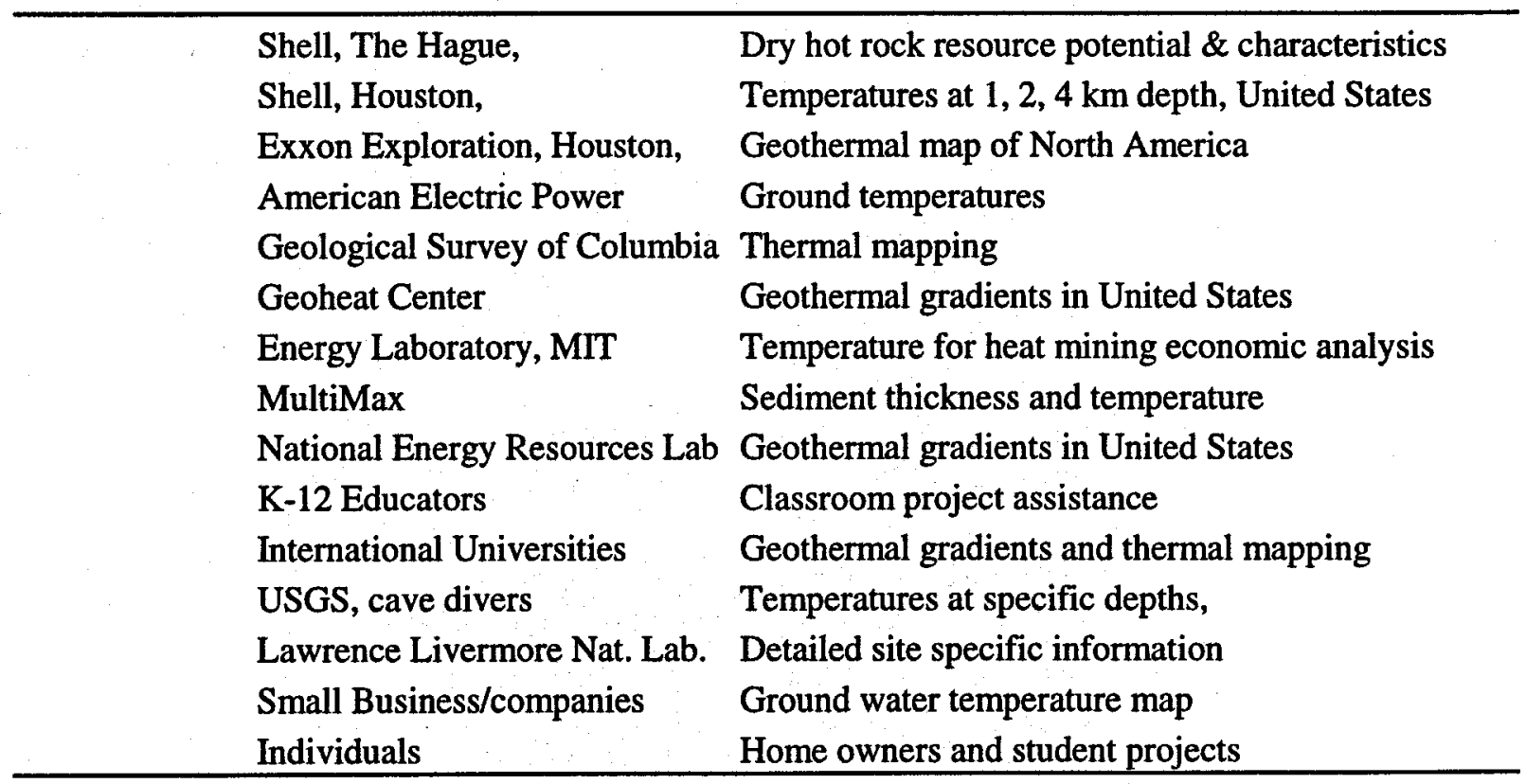

\subsection{CONCLUSIONS}

Geothermal resource estimates and assessments by this and other projects are supported by making available the most up to date heat flow, geothermal gradient, and thermal conductivity information in useful digital formats. Distribution of the results in digital form via the World Wide Web on the Internet was part of the project. Although this is the final year of the project, the web site will continue to be updated. There are already over 1000 additional data points collected for future incorporation in the database. There is a new project to update the DNAG United States geothermal map and this will also generate new data and use for the data from the Western Regional database. We will continue to keep updated results available by operating the web page and respond to inquiries generated from this site. 


\subsection{INSIGHTS INTO EXTENSIONAL GEOTHERMAL SYSTEMS FROM NUMERICAL MODELING}

\subsection{INTRODUCTION}

There are two major similarities in extensional systems of the Basin and Range: (1) strongly faultrelated near-surface upflow, and (2) lack of any evident crustal magmatic heat 'sources (Yeamans, 1983). While there is general agreement that the upflow in most Basin and Range geothermal systems is fault controlled, the effect of the permeability structure on these systems is still debated (Wright, 1991). These non-magmatically driven, fault controlled geothermal systems are termed extensional systems in this report.

Most studies of extensional systems, including those based on numerical modeling, have focused on the near-surface reservoir with a view towards reservoir exploitation (Sorey and Olmstead, 1994). The generally accepted qualitative models of extensional systems postulate fluid circulation predominately perpendicular to, and occasionally within the range-front fault. There has been little effort to systematically determine the basic relationships between system configuration (e.g. permeability and structure) and the resulting thermal-flow behavior of the geothermal system. Notable exceptions are the studies of Forster and Smith (1988a\&b, 1989), which considered mountainous terrain systems, and Lopez et al. (1994, 1995, 1996), Welch, Sorey and Olmsted (1981), and Sorey and Olmsted (1994), which simulated three-dimensional systems with a focus on in-the-fault-plane circulation.

Heat and water, two prime ingredients for a geothermal system, are present throughout the Basin and Range. Permeable upflow paths are also needed in order for heated water to return quickly to the shallow sub-surface. Faulting provides these paths. The Basin and Range is heavily faulted throughout, so why then are geothermal systems only associated with relatively recent faulting? The answer is that self-sealing - the process where cooling, ascending fluids precipitate minerals in pore space (thereby reducing permeability) - will eventually limit or eliminate flow.

Field studies have found extensive sealing in exhumed faults. Parry et al. (1991) found extensive hydrothermal alteration and fracture filling at all scales on the exposed footwall along the southern part of Dixie Valley fault. Similar pervasive geothermal alteration and sealing has been found on other faults in the region (Parry et al., 1988; Vikre, 1989). Precipitation could be orders-of-magnitude faster on the lateral boundaries of a flow conduit than along its length due to steep temperature and pressure gradients. Thus it is likely that a conduit such as a fault would, for most of its lifetime, have low permeability lateral barriers.

\subsection{METHODS}

The numerical code used to solve the coupled, non-linear equations of heat and fluid flow was TOUGH2. The code has been verified, as defined by Anderson and Woessner (1992). TOUGH2 (Transport Of Unsaturated Groundwater and Heat 2) is a multi-dimensional, Integrated Finite 
Difference (IFD) code for fluid and heat flow (Pruess, 1987, 1991, 1997). TOUGH2 is a refinement of the MULKOM code system developed at Lawrence Berkeley Laboratory. For this study a slight change was made to the published version of TOUGH2 for PCs. The maximum number of elements and connections was increased to accommodate the models in this study. A bibliography relating to TOUGH2 is available on the internet at http://ccs.lbl.gov/TOUGH2/BIBLIOGRAPHY.html.

The majority of the models covered a broad range in basal heat flow $\left(30 \mathrm{~mW} / \mathrm{m}^{2}\right.$ to $\left.120 \mathrm{~mW} / \mathrm{m}^{2}\right)$ and host rock permeability configurations $\left(10^{-15} \mathrm{~m}^{2}\right.$ and $\left.10^{-18} \mathrm{~m}^{2}\right)$. Host rock is taken to be all rock except the valley fill and fault zone. Other series were run to evaluate fault permeability $\left(3.0^{*} 10^{-15} \mathrm{~m}^{2}\right.$ to $\left.2.0^{*} 10^{-12} \mathrm{~m}^{2}\right)$, rock thermal conductivity $(0.8-3.0$ times the base configuration), degree of self-sealing along the upflow path $\left(10^{-15} \mathrm{~m}^{2}\right.$ and $\left.10^{-18} \mathrm{~m}^{2}\right)$, and valley fill permeability (ratios of horizontal to vertical permeabilities between 1 and 100). In all models, all rock properties, including porosity and permeability are constant within a given unit. In other words there is specifically no variation with depth or time (e.g. compaction or consolidation). All rock unit properties are also isotropic except for valley fill permeability.

The base model used in this report consists of a vertical cross section of a generic Basin and Range valley (Figure 10). The model is $27 \mathrm{~km}$ wide by $8.75 \mathrm{~km}$ deep (top of range to bottom of the model). The model has 4782 cells (or elements) and 4932 nodes. Elements range in size from $5762 \mathrm{~m}^{2}$ in the fault zone to $30,1872 \mathrm{~m}^{2}$ outside the area of interest (the models are assigned a thickness of one meter). While TOUGH 2 can handle $n$-sided cells, all modeling was conducted with rectangular elements due to limitations with meshing algorithms in the Argus ONE software used to create the models.

The model domain is larger than often seen in system studies - it extends beyond the range and valley of interest to include part of the next range and valley to either side. The ranges are $5 \mathrm{~km}$ wide at the base and have a relief of $0.75 \mathrm{~km}$. The valley floor is horizontal, and $9 \mathrm{~km}$ wide (Figure 10). These dimensions are representative of a typical basin and range.

The fault zone is planar, and dips $60^{\circ}$. The $60^{\circ}$ dip was chosen to be representative of the upper portion of a typical Basin and Range fault. The fault extends to $4 \mathrm{~km}$ below the valley floor. This fault depth is somewhat less than might be expected for a typical fault. The fault depth assumed was a compromise between the desire to allow for ample room below the base of the fault for fluid and heat flow such that the bottom boundary would not abruptly truncate flow paths, and the need to keep the model less than $9 \mathrm{~km}$ tall (due to the limits of the fluid equation of state module). The surface break of the fault is at the base of the range, in the valley. There are separate zones on each side of the fault that are used to represent barrier zones. These barrier zones can be used to simulate self-sealing. The valley fill was divided into several layers to provide the capability of representing shallow outflow zones, but for the models reported here, the valley fill was treated as one unit (i.e. all four layers had identical properties). 


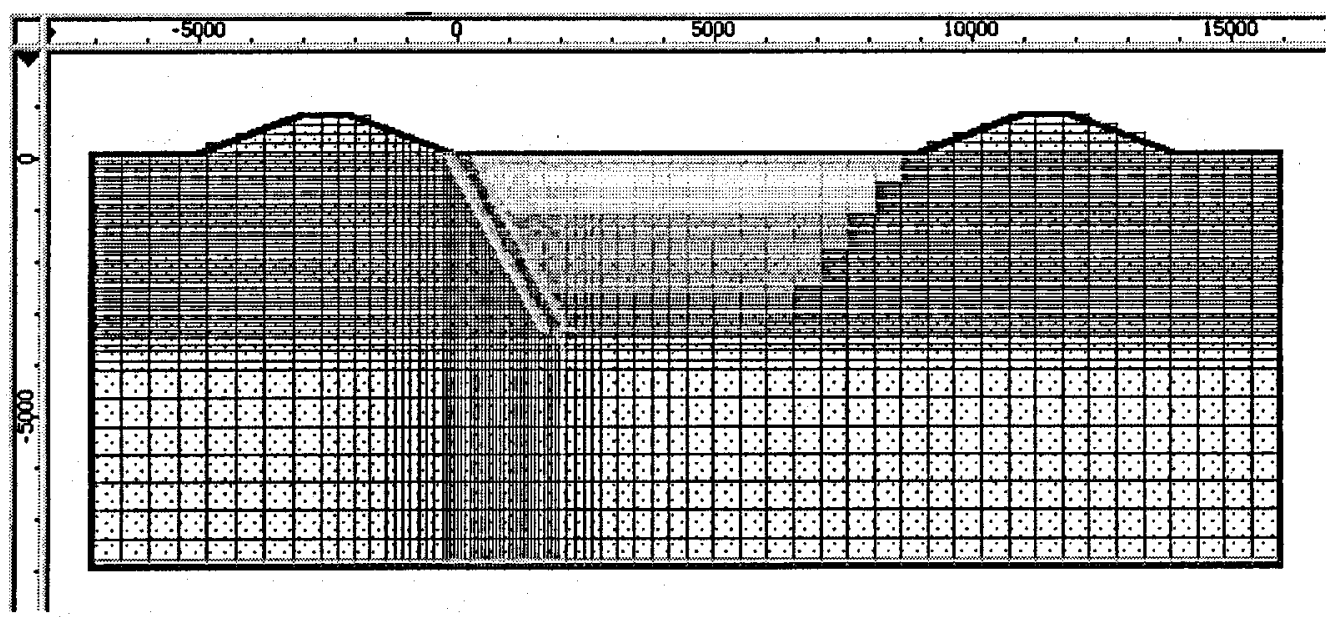

Figure 10. Model Mesh. Model dimensions are in meters. The bulk of the model consists of one rock unit (dark). The valley fill is divided into several units (shades of gray), but was treated as one for all cases. The fault zone is bracketed by barrier zones. Apparent gaps in element spacing in the high-density regions are a display artifact.

Boundary conditions for all TOUGH2 models are as follows:

1) Top set at a constant pressure of $1 \mathrm{E}+05 \mathrm{~Pa}$ (atmospheric) and temperature of $20^{\circ} \mathrm{C}$

2) Sides set at no heat or fluid-flow

3) Bottom set at no fluid-flow, with constant heat flux into the model.

The top boundary was set at representative surface conditions. No thermal lapse rate was included, as this would have an insignificant effect on the model. The water table was set at ground level in the model. No attempt was made to represent the unsaturated zone. The complexity that would be added to the model by representing the near surface environment in detail would add little to the understanding of a generic geothermal system.

Initial conditions for the first model run in all series were a roughly linearly increasing (hydrostatic) pressure and temperature with depth. For subsequent runs in a series, the solution of the first run was used as the starting point. As a check, some models were run from both sets of initial conditions. In these runs there was no difference in the final (steady state) solution. Default iteration and solution criteria, as defined in Pruess (1987, 1991), and Moridis and Pruess (1995), were used in all models.

\subsection{RESULTS}

Detailed results are described by Wisian (1999 2000). Representative model results for a basal heat flow of $90 \mathrm{~mW} / \mathrm{m}^{2}$ and $10^{-16} \mathrm{~m}^{2}$ bulk permeability, are shown in Figures 11 , and 12 . This model is a successful model in the sense that high temperatures can be found along the fault zone but the regional heat flow is not drastically affected by the flow system. The primary flow path in most models (as illustrated specifically for the model shown on Figure 10) is basically down in the ranges, horizontal through the basement at depths of 4 to $9 \mathrm{~km}$, and focused flow up the fault. Secondary flow systems are present on the flanks of the ranges and in the valley fill. Most of the fluid circulates to depths 
below the bottom of the high permeability region used to model the fault zone. Isotherms are depressed under the ranges and elevated near the fault (as would be expected). In the permeability range assumed in this model the thermal structure in the range is not modified in a major way from the conductive state. As the permeability of the basement is increased the heat flow in the ranges is depressed by the more active fluid circulation.

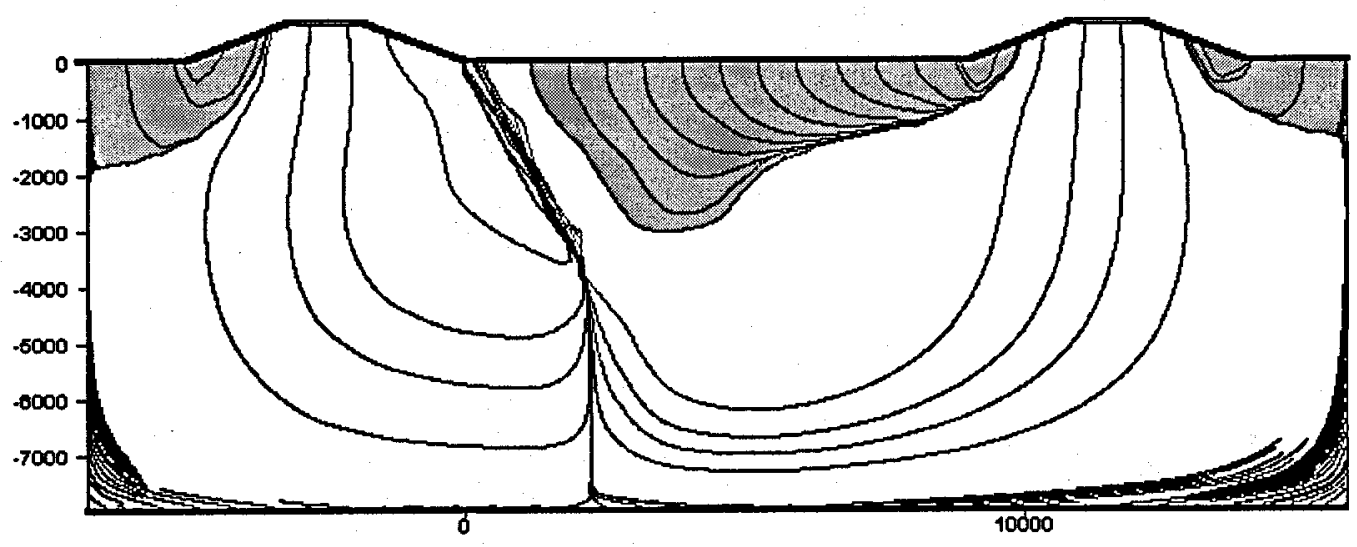

Figure 11. Flow paths for typical TOUGH2 model. Representative particle paths are shown (not stream functions). The bulk of the flow circulates to depths of 4 to 7 kilometers before returning to the surface. The shallow flow systems (shaded) reach no deeper than $2 \mathrm{~km}$ in most models.

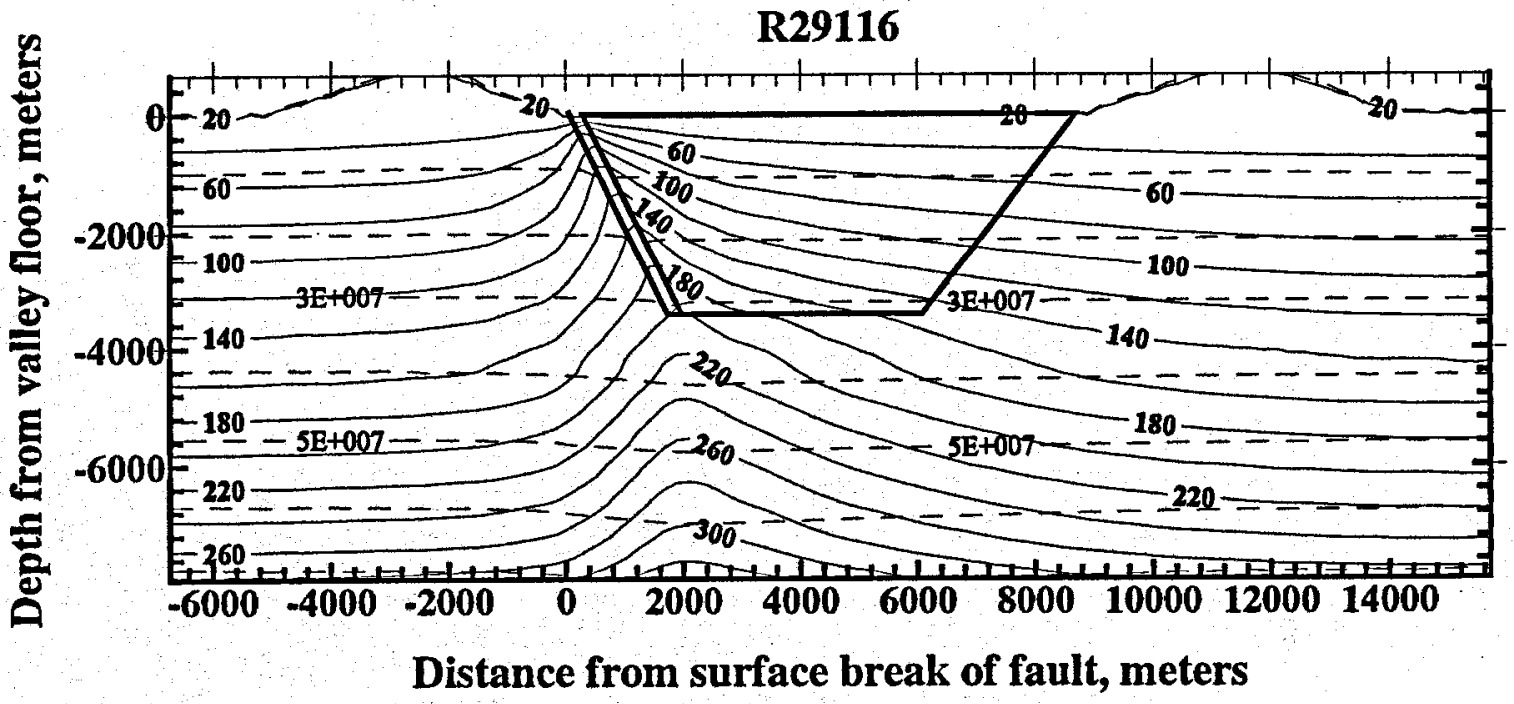

Figure 12. Temperatures and pressures in model R29116 $\left(90 \mathrm{~mW} / \mathrm{m}^{2}\right.$ basal heat flow, $10^{-16} \mathrm{~m}^{2}$ bulk rock permeability). At this permeability, the thermal regime is between convection and conduction dominated states. The isotherms show significant depression under the ranges and pull-up in the fault due to fluid flow. 
Figure 13 shows temperature-depth curves at various locations in the model. This is the information that is collected in the exploration and development of a geothermal system so the shapes are of particular interest. The characteristics of the temperature-depth curves are dependent on where they are in relation to the upflow zones. Plots that cross the fault zone show an inflection of varying sharpness depending on distance from the fault surface break. Note that temperature-depth plots from the range show only subtle indications of fluid recharge (the shallow isothermal section).

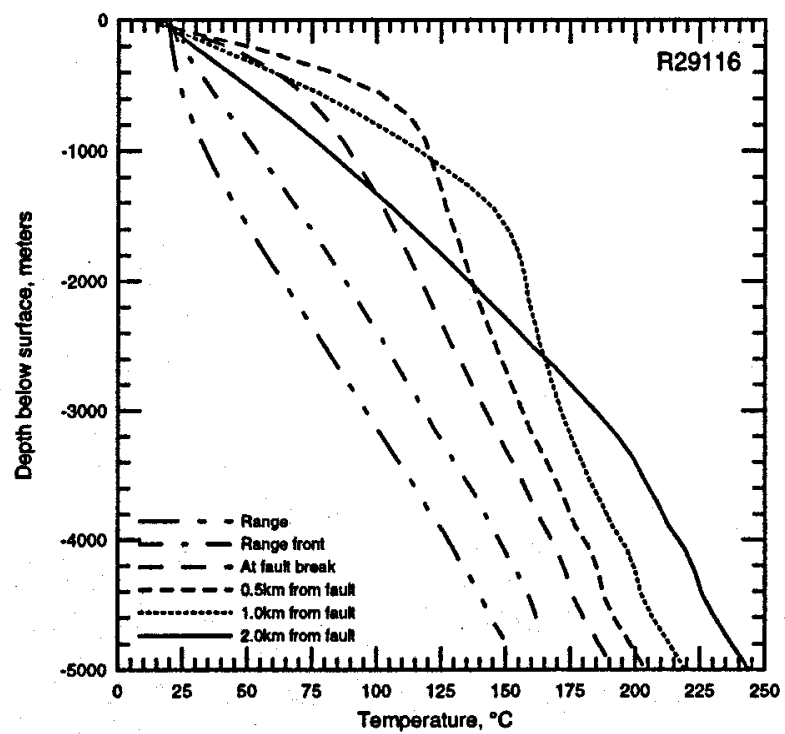

Figure 13. Temperature-depth curves for various locations in model R29116.

Fluid upflow is clearly recognizable in the T-D plots from the fault and further into the valley. Even though there is strong downflow under the ranges, the range and range front $T-D$ curves look qualitatively similar to conduction dominated cases.

A number of other models are discussed elsewhere (Wisian, 1999, 2000). Because that information is available elsewhere only the overall results are described here. To discuss the results for all the model series, it is necessary to determine what parameters are of most interest. Flow fields and temperature isotherms are of course important to see, but it is not possible to keep dozens of graphs in mind. A more concise measurement of the results of many models is needed. To that end, total heat flow up the fault and fault temperatures were used as overall descripters of a model.

Heat flow and temperature vary continuously along and across the fault in all models, so some rational for quantifying these values is needed. In the plots that follow, temperature and heat flow are measured $0.5 \mathrm{~km}$ below the valley floor. Heat flow is determined by summing the conductive and advective heat flux across the fault. Temperature is an average of the temperature in the cells that are in the fault zone at $0.5 \mathrm{~km}$ depth (plus or minus one cell). The $0.5 \mathrm{~km}$ depth of measurement obviously impacts the values. As shallow a point as practical is desired so that all the heat that is captured by the fault is focused into a limited area. From the point of real-world applicability as well, a shallow point of measurement is desired. Most temperature measurements are made in the upper one or two kilometers of the crust. Also, from an economic point of view, production is usually in the 
same depth range, so again it is the shallow thermal regime that is of interest. Model boundary effects and the shallow outflow zone need to be avoided when quantifying a model thermally. A depth of 0.5 $\mathrm{km}$ gets safely below the impact of any effects due to the coarseness of the air/surface interface. Figures 14 and 15 summarize the results of all of the model runs by comparing temperature and heat flow up the fault (at $0.5 \mathrm{~km}$ below the valley floor) to host rock permeability.

The main feature apparent in Figures 14 and 15 is a peak in temperature and heat flow up the fault for bulk permeability in the $10^{-16} \mathrm{~m}^{2}$ to $10^{-15} \mathrm{~m}^{2}$ range. In addition the peaks shift to lower permeability with increasing heat flow. Another parameter of interest, the maximum temperature in the fault, shows more dependence on basal heat flow than the heat output of the fault. In all cases the maximum temperature occurs at a slightly lower permeability than maximum heat flow, because of a trade-off between the volume of fluid moving up the fault and the temperature of the fluid.

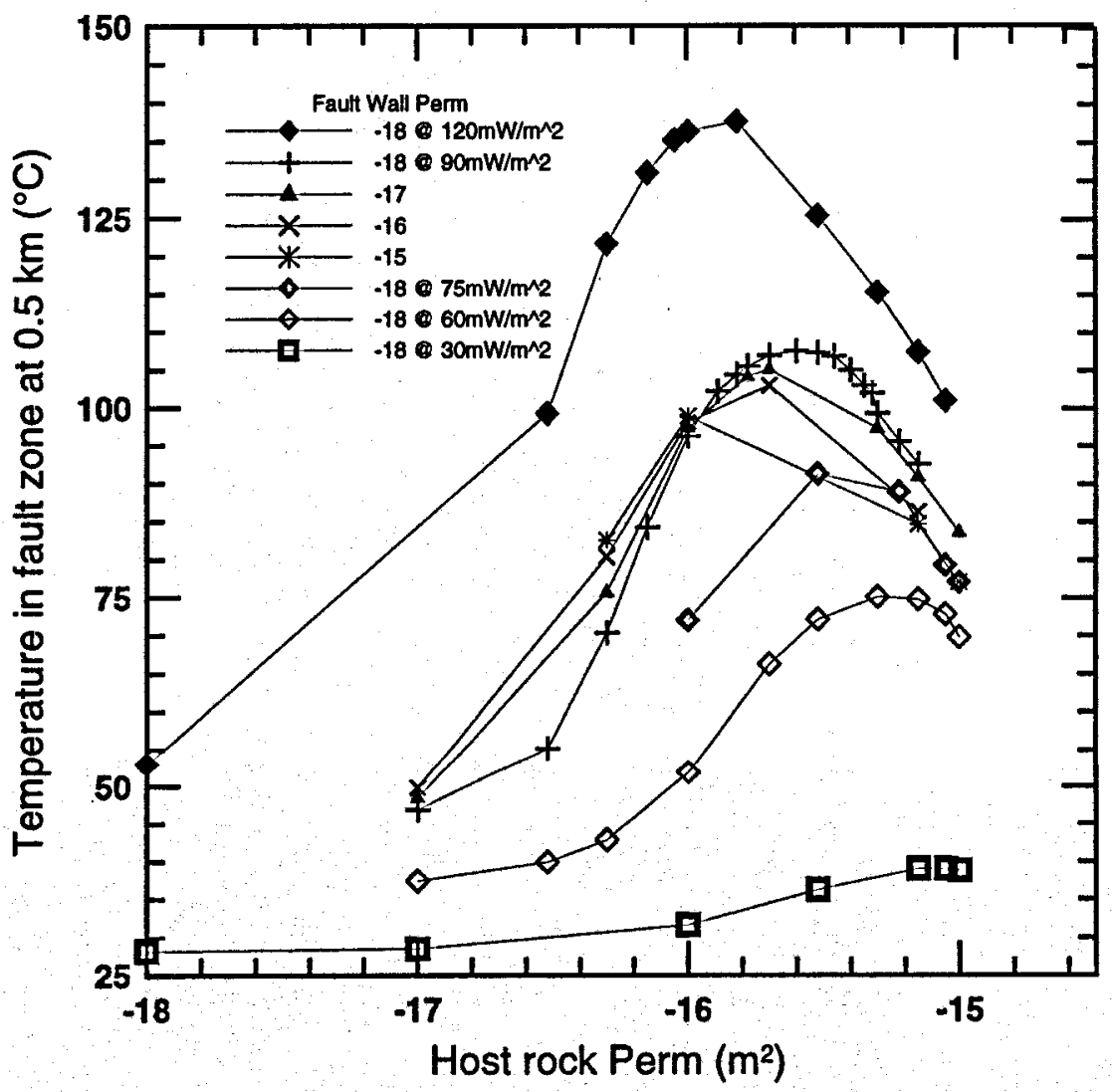

Figure 14. Fault temperature versus host rock permeability. At $10^{-18} \mathrm{~m}^{2}$ bulk rock permeability temperatures reflect a conductive regime. As permeability increases, so does temperature in the fault, until reaching a maximum between $10^{-16} \mathrm{~m}^{2} 10^{-15}$ $\mathrm{m}^{2}$ (depending on basal heat flow). At permeabilities higher than the peak, fluid flow is so vigorous that the models begin to "wash out" and the temperature declines. 


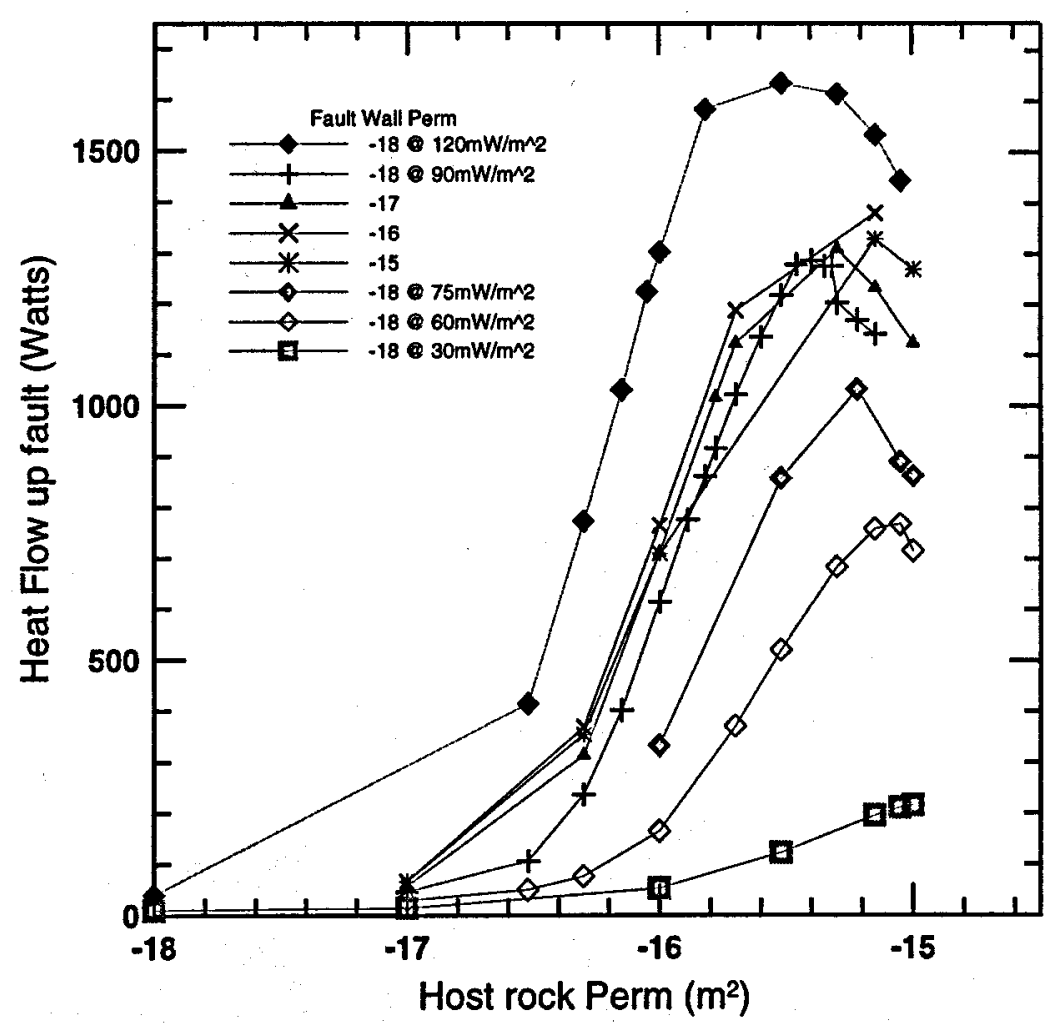

Figure 15. Heat flow up the fault versus host rock permeability. The pattern is similar to that for the temperatures in the fault.

\subsection{DISCUSSION}

For basal heat flow between $30 \mathrm{~mW} / \mathrm{m}^{2}-120 \mathrm{~mW} / \mathrm{m}^{2}$, temperature and heat flow in the fault versus bulk rock permeability are qualitatively similar. All situations start at a conductive state when the permeability is greater than $10^{-18} \mathrm{~m}^{2}$. As permeability increases, convection starts (at lower bulk permeability with increasing basal heat flow). At $10^{-17} \mathrm{~m}^{2}$, temperatures and heat flow are only slightly higher, in all cases, than at $10^{-18} \mathrm{~m}^{2}$, but by $10^{-16.5} \mathrm{~m}^{2}$ all the plots (except $30 \mathrm{~mW} / \mathrm{m}^{2}$ ) show clear increases from conductive states - indicating the onset of convection. From the start of convection, all the profiles increase steadily until the increasing convection starts to "wash-out" the thermal structure in the system, thereafter the temperature and heat flow start to decrease. The decrease continues through $10^{-15} \mathrm{~m}^{2}$, the highest bulk permeability that could be practically simulated. Above this value, fluid and heat flow was so vigorous that the code reduced the solvable time step to unrealistically short increments. Similar results for models with a (more limited) range of permeability and heat flow have been published for a low temperature mountainous environment, by Forster and Smith (1989). Lopez and Smith (1995), also found the same type of dependence on bulk permeability for their geothermal system models.

One series of models, at $90 \mathrm{mWm}^{2}$ basal heat flow, was run to evaluate the effect of self-sealing barriers. For these runs the permeability of the units on either side of the fault was varied between $10^{-18}$ and $10^{-15} \mathrm{~m}^{2}$. The resulting heat flow and temperatures in the fault show relatively little variation 
related to the change in permeability around the fault. Thus, as long as a permeable central path exists, the degree of self-sealing has only a minor effect on the geothermal system (for this particular geometry).

There is a slight, but sharp decrease in temperature and heat flow up the fault at permeabilities slightly greater than that for the peaks in the respective curves (e.g. around $10^{-15.3} \mathrm{~m}^{2}$ for $90 \mathrm{~mW} / \mathrm{m}^{2}$ basal heat flow). This drop is due to the development of secondary convection cells in the model. These cells start in the two outboard valleys when the bulk permeability is such that it is easier for the deep circulation under the valleys to exit within the valley rather than cross the range and exit at the fault. At this point the contrast between bulk and fault permeability is approximately one order of magnitude. Small cells initiate (with increasing permeability) in the lower outboard corners and rapidly expand to discharge at the surface. These models show that an easy "escape path" such as a permeable fault path can induce significant cross-range flow even without a regional topographic/hydrologic slope.

To isolate the effect of topography on geothermal system development, a series of models identical to the $90 \mathrm{~mW} / \mathrm{m}^{2}$ basal heat flow models were run, but with no topography. For this series, the top of the model was a flat surface at the level of the valley floor. All other variables and boundary conditions are the same. Figure 16 shows the results of the "flat top" models expressed in terms of Nusselt number. The Nusselt number is the ratio of heat transferred by fluid movement to that transferred by conduction. As with other non-dimensional numbers used in porous media flow, $\mathrm{Nu}$ is defined in many subtly different ways according to circumstances. Here $\mathrm{Nu}$ is defined as;

$$
N u=\frac{H F_{t}}{H F_{c}}
$$

Where $H F_{t}$ is the total heat flow up the fault $0.5 \mathrm{~km}$ below the surface, and $H F_{c}$ is the heat flow up the fault at a bulk permeability of $10^{-18} \mathrm{~m}^{2}$ (i.e. conduction dominated state).

Thus the development of a geothermal system with respect to bulk permeability of the basement is qualitatively the same with and without topography. Topography provides an extra "kick" to convection compared to flat top models so that convection starts at slightly lower permeability with topography, and is somewhat stronger. The maximum Nusselt number (and similarly the maximum heat flow up the fault) for the system with topography is $\sim 20 \%$ higher than for the system with no topographic relief. Peak temperatures within the fault for the two systems are within $1^{\circ} \mathrm{C}$ (flat top systems are slightly lower). Besides being offset to higher permeability, the peak in temperature for the flat system is also broader. The occurrence of higher total heat flow up the fault, for the system with topography versus the system without, even though the maximum temperatures are nearly the same, indicates that the system with topography is pushing more fluid through the fault. 


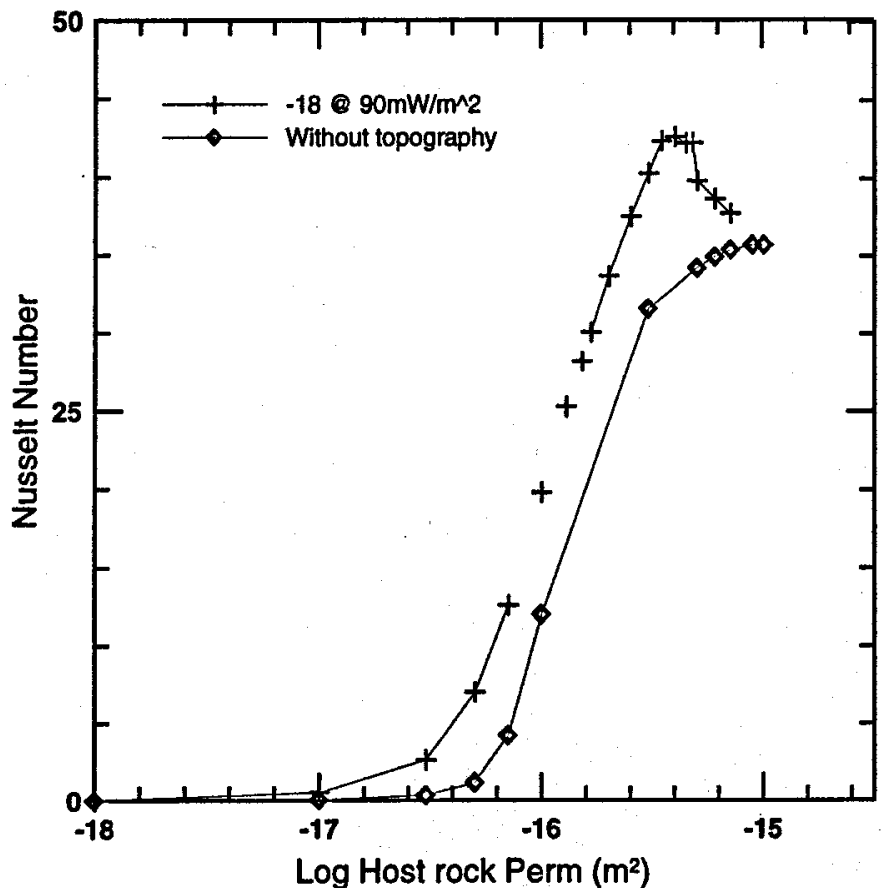

Figure 16. Nusselt Number for systems with and without topography. Qualitatively the convective heat transfer develops similarly for systems without topography compared to systems with topography. Topography gives an earlier start (around $10^{-17} \mathrm{~m}^{2}$ bulk permeability) versus flat systems $\left(10^{-}\right.$ ${ }^{16.5} \mathrm{~m}^{2}$ ) and greater total heat movement up the fault.

Reservoir Temperature The economic viability of a geothermal system is dependent on the maximum fluid temperature. The temperatures determined by these (relatively idealized) models are not necessarily what would be expected to occur in a similar real-world situation. Several factors result in the maximum model temperatures being less than what would be expected in the real world. The base fault permeability is slightly below the value for maximum temperature, resulting in a temperature about $10 \%$ below the maximum possible. The numerical discreetization and porous media representation do not allow accurate modeling of fast, narrow, high temperature flow in fault zones. Also, the sampling of fault temperatures deliberately trims the peak by about $5 \%$ (due to averaging across the fault zone).

Reservoir temperatures are a key measure of geothermal systems as these represent a practical limit to the maximum temperatures that can be exploited for power production. Reservoir temperature is defined here as the highest temperature at which the bulk of the geothermal fluid chemically equilibrates. It is a quantity that can be measured relatively well for real-world systems, and can be extracted from model results. Other points of comparison between real-world and model systems are not as general. Temperature and heat flow at any particular point in a geothermal system are subject to site-specific variations. Reservoir temperatures for real-world systems are usually based of geochemical thermometers, which record the last temperature at which the fluid sample chemically equilibrated. Major assumptions implicit in geochemical temperatures are that the fluid is not diluted by other sources, and that there is no partial re-equilibration at lower temperature between the reservoir and sample location. There are many other cautions and nuances associated with using geochemical measurements to derive reservoir temperatures, but it is well beyond the scope of this 
study to discuss them in detail. The reader is referred to Nicholson (1993) for an overview and further references.

Geochemical reservoir temperatures were collected for extensional geothermal systems from a variety of open and proprietary sources, primarily from Mariner et al. $(1974,1983)$ and Garside and Schilling (1979). Background heat flow values were determined for each system based on the latest heat flow map of the United States (Wisian et al., 1999). Figure 17 shows the reservoir temperatures along with lines of maximum temperature for a given depth of circulation for system thermal conductivities of 2.0 and $1.5 \mathrm{~W} / \mathrm{m} / \mathrm{K}$. Also shown are the reservoir temperatures from each basal heat flow series (from the model with the maximum temperature at $0.5 \mathrm{~km}$ depth). Model reservoir temperatures were determined by inspection of isotherms and flow paths for each model to determine the highest temperature reached by the majority of the fluid.

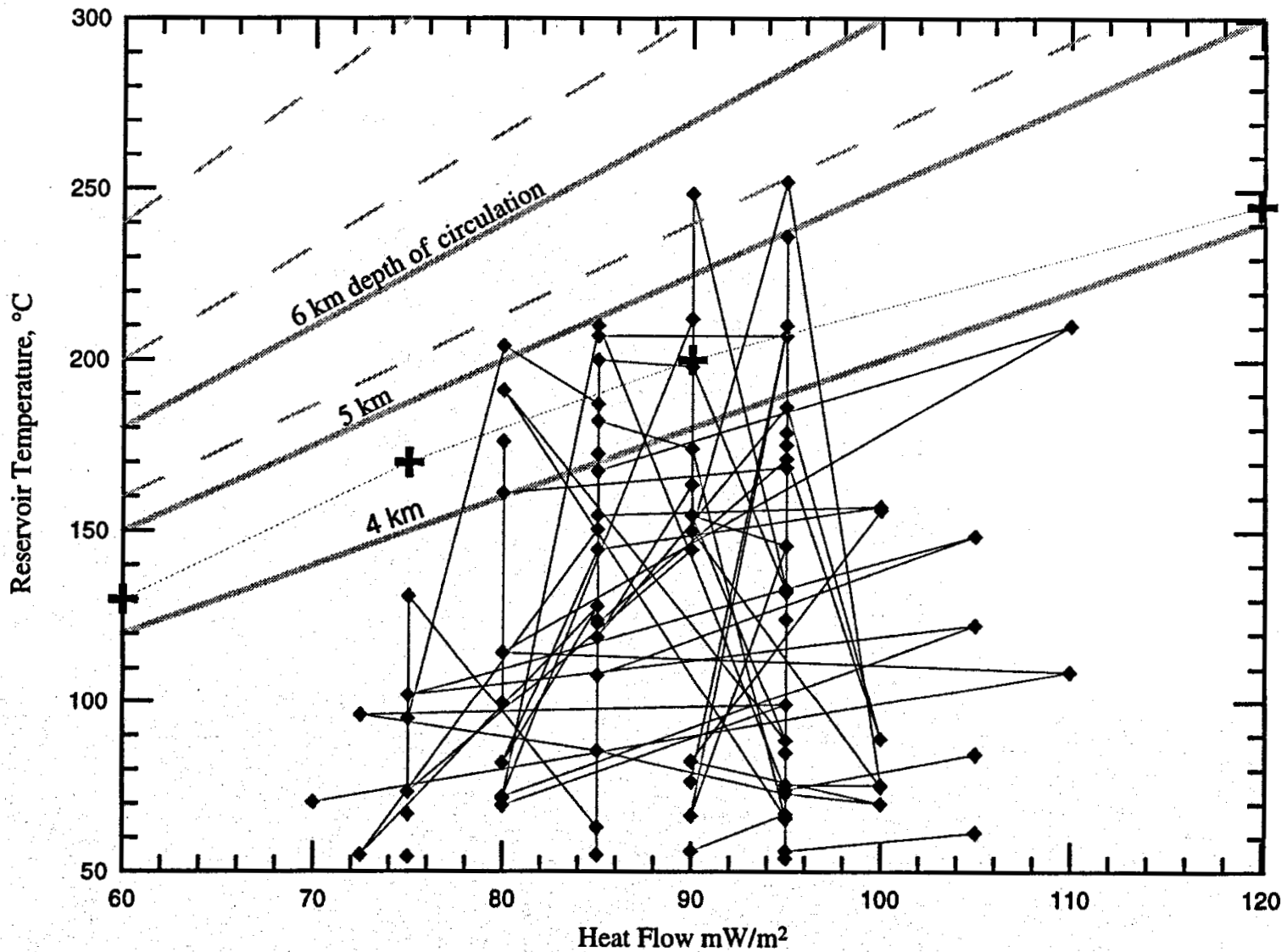

Figure 17. Model reservoir temperatures (pluses) and geothermal system reservoir temperatures (diamonds) versus basal (background) heat flow. Gray lines are the depth of circulation to achieve a given reservoir temperature for an overall system thermal conductivity of $2.0 \mathrm{~W} / \mathrm{m} / \mathrm{K}$. Dashed gray lines are for a thermal conductivity of $1.5 \mathrm{~W} / \mathrm{m} / \mathrm{K}$ (after Wisian et al., 1999). 
Model reservoir temperatures fall in the middle of the highest real world reservoir temperatures between 80 and $95 \mathrm{~mW} / \mathrm{m}^{2}$ (this is the range with statistically reliable sampling) indicating that these models are representative of Basin and Range systems in general. The model reservoir temperatures fall at the 4 to $4 \frac{1}{2} \mathrm{~km}$ depth of circulation point (based on $2.0 \mathrm{~W} / \mathrm{m} / \mathrm{K}$ thermal conductivity), despite much of the flow passing depths of $6 \mathrm{~km}$ below the valley floor. Thus the usual method of estimating depth of circulation $D$;

$$
D=\frac{T_{\text {res }}-T_{\text {surface }}}{\nabla T}
$$

where

$$
\nabla T=\frac{H F}{k}
$$

and $H F=$ heat flow, $k=$ thermal conductivity, may underestimate the true value by $30 \%$. Although it is generally realized that the above calculation of circulation depth is simplistic, it is an industry standard, and the potential error has not previously been quantified.

Comparing the depth of circulation projections with the geochemical reservoir temperatures shows that, depending on overall thermal conductivity, high temperature geothermal systems in the western U.S., effectively circulate to minimum depths of about 4-6 km (not including the above $30 \%$ correction). A $6 \mathrm{~km}$ maximum flow depth is well above the projected brittle-ductile transition of $\sim 15$ $\mathrm{km}$ in the Great Basin, where most extensional geothermal systems are located (Rogers et al., 1991). In general, water is expected to be present and at least somewhat mobile throughout the brittle crust. For almost any permeability and above average heat flow, the critical Rayleigh number $\left(\mathrm{Ra}_{\text {crit }}\right)$ for the onset of natural convection is exceeded (Straus and Schubert, 1977). So why are reservoir temperatures not higher?, i.e., why are we not seeing temperatures of $400^{\circ} \mathrm{C}$ and higher from fluid circulating to near the brittle-ductile transition? Fluid systems would not be expected to work well above the critical point $\left(-375^{\circ} \mathrm{C}\right)$, which is somewhat of a natural limit. Critical point temperature though is still much higher than the reservoir temperatures seen here. There are many factors that could be limiting most fluid flow to the upper third of the brittle crust (e.g. loss of porosity and/or permeability due to pressure, or diagenesis could stop circulation). Perhaps the geochemical temperatures represent an intermediate stage reservoir or partial re-equilibration between maximum depth and the surface. There are also well known, significant variations in geochemical thermometer results depending on how they are used and interpreted (Fournier, 1990, Nicholson, 1993).

\subsection{CONCLUSIONS}

Basic qualitative relationships between structure, heat input, and permeability distribution, and the resulting extensional geothermal system have been determined based on numerical modeling of a typical basin and range geometry. An extensional geothermal system is found to exist only in a relatively narrow range of bulk permeability $\left(10^{-15}-10^{-16} \mathrm{~m}^{2}\right)$. Outside of this window temperatures in the shallow sub-surface area of the geothermal system decrease rapidly. The presence of a relatively 
more permeable upflow path (provided by geologically recent faulting) is also a requirement for system development. Combined with the need for above average (continental) heat flow to reach usefully high reservoir temperatures, a fairly specific set of conditions for geothermal system development can be defined.

Maximum temperatures in, and heat flow up, the fault are proportional to basal heat flow (background or regional heat flow in geologic terms). While topography gives an extra, early "kick" to circulation, it is not a requirement for system development. In the generic geothermal system model, flow from the ranges to the fault dominates the circulation, while secondary flows exist on the range front slopes. A permeable fault in one valley can also induce cross-range flow from adjacent valleys if there are no equally good upflow paths in the adjacent valleys. When bulk permeability is high enough, additional deep circulation cells develop in adjacent valleys, diverting heat and fluid from the fault and consequently reducing temperatures. Most extensional systems in the US appear to circulate to depths of 4 to 6 kilometers based on a common extrapolations. These estimates may be up to $30 \%$ too shallow based on comparison with numerical models. While there are many factors that remain to be evaluated, the basic quantitative relationships are emerging. 


\subsection{STRUCTURE OF THE DIXIE VALLEY GEOTHERMAL SYSTEM FROM GRAVITY DATA}

\subsection{INTRODUCTION}

The structure of Basin and Range faults and the manner in which that structure relates to geothermal systems has been subject of long and extended discussion as graphically illustrated by the history of models of the Dixie Valley geothermal field (Benoit, 1999). It is a typical Basin and Range system in the sense of the location, but has the highest temperatures $\left(248^{\circ} \mathrm{C}\right.$ Oxbow area, $285^{\circ} \mathrm{C}$ Dixie Valley Power Partners area) found in the province in a nonmagmatic system, and lies along one of the most active normal fault systems in the Basin and Range (Bell and Katzer, 1987; Caskey et al., 1996). The Dixie Valley normal fault system is the contact of the Stillwater Range and Dixie Valley in Churchill and Pershing counties, western Nevada. Blackwell et al. (1999b) discussed the structure of the range/valley contact as it relates to the geothermal system based on an analysis of a number of data sets and that discussion is summarized here. Additional information on the thermal regime will be published in the Proceedings of the World Geothermal Congress 2000 (Blackwell et al., 2000).

The models of the range bounding fault in Dixie Valley span the gamut from low angle or listric (Plank, 1998; Plank et al., 1999) to high angle (e.g. Okaya and Thompson, 1985) and from single to double stranded. There are numerous published studies that argue various interpretations of the structure. However, in spite of abundant seismic reflection data and other information the details of the range bounding structures have been unclear. The model that has been used for most of the development of the geothermal system in Dixie Valley has been that of a range bounding fault dipping at $54^{\circ}$ toward the basin (Benoit, 1999). This dip is based on the assumption that the fault encountered in the producing wells connects to the range/valley topographic contact (Figure 18). The wells are all at about the same distance from the range front and until recently there was little thermal or drilling information between the producing wells and the range front. As a result the dip of the structure associated with the production is constrained by drilling information only between depths of 2 and 3 $\mathrm{km}(6,000$ and $10,000 \mathrm{ft})$.

In 1993/1994 two wells, 62A-23 and 36-14, were drilled by Dixie Valley Power Partners (DVPP) in a block of sections (diagonal rule pattern on Figure 18) to the south of the Oxbow field. Temperatures in $62 \mathrm{~A}-23$ reached $267^{\circ} \mathrm{C}\left(5.13^{\circ} \mathrm{F}\right)$, but no producible fractures were encountered while temperatures in $36-14$ reached $285^{\circ} \mathrm{C}\left(545^{\circ} \mathrm{F}\right)$ and the well produced from fractures near the bottom of the well (Blackwell et al., 2000). Even further to the south two deep, hot wells were drilled in the early 1980's (66-21 and 45-14) that have artesian flow, but are not commercial producers. Also there is geologic evidence for long-term and extensive high temperature fluid flow all along much of the exposed part of the Dixie Valley fault system (Parry et al., 1991).

Also shown on Figure 18 is the inferred position of the range-bounding fault (at the edge of the topographic break between Dixie Valley and the Stillwater Range). In addition to that line, several subparallel high-angle normal faults were mapped within the bedrock of the range by Plank (1998). Several areas of active thermal manifestations are found along the range front such as the Senator 
fumaroles. Large areas along the range front may be covered by landslides. The geology of the Stillwater Range has been described by Speed (1976) and in more detail in the vicinity of the Oxbow field by Plank (1998).

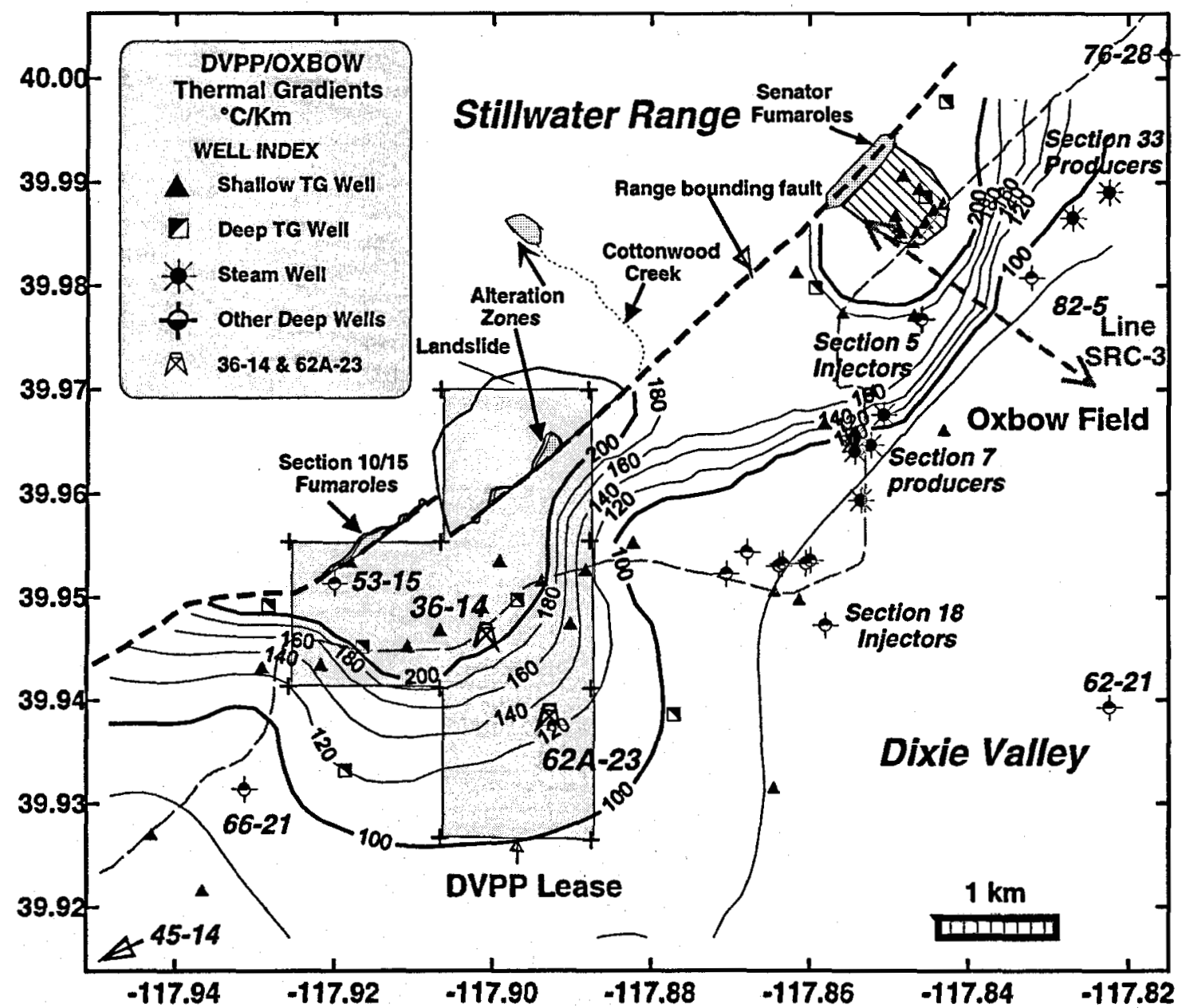

Figure 18. Index map of the Dixie Valley geothermal system. Shallow over flow from the Senator fumaroles (Allis et al., 1999) is shown by ruled pattern.

\subsection{PROBLEMS WITH THE SINGLE FAULT MODEL}

One of the "advantages" to the study of the structure of the range bounding fault in this area compared to other areas in the Basin and Range province is that there are a number of seismic profiles in the valley. These reflection profiles have been obtained by several different groups and there have been several publications related to presentation and interpretation of the results (UURI, 1981; Okaya and Thompson, 1985; Honjas et al., 1998, Louie et al., 1999). However, the seismic data have not been involved in the development of a geothermal model of the valley/range contact. The reflection technique as usually employed is designed to image structures or beds that are flat lying or have a low dip in regions of low horizontal velocity contrasts. Thus the steep nature of the range/valley contacts 
causes problems for reflection data collection and interpretation. Interpretation techniques, such as migration, that are designed to partially mitigate these short comings have become common since the data were collected in the early 1980 s, but have only recently been applied to these old profiles (e.g. Honjas et al., 1998).

The seismic reflection interpretation most commonly cited (of SRC-3; Okaya and Thompson, 1985) is shown in Figure 19 and the location of the SRC-3 section is shown on Figure 18. The features of this interpretation that were emphasized were the single $50^{\circ}$ dipping fault that bounds the Stillwater Range and the broken up reflections on the reflection section southeast of the interpreted fault. The broken nature of the seismic profile was attributed to disturbance of the signal by scattering in a coarse alluvial fan sequence adjacent to the range on the downthrown side of the fault. The source of these coarse clastics was attributed to rapid erosion of the uplifting Stillwater Range.

One problem with this seismic interpretation became obvious from analysis of the thermal and drilling data from the deep wells. The seismic interpretation requires the section to be dominated by very coarse clastics that would be expected to be very permeable. During the drilling of the geothermal wells, lost circulation and drilling problems commonly associated with highly permeable formations are very rarely found in the valley fill section of the wells and water flow seems to be very limited below depths of more than 100 to $200 \mathrm{~m}$. Based on the wells logs the deep wells have not encountered much coarse alluvial material. Furthermore the limited thermal information above the reservoir suggests that conductive conditions dominate the heat transfer except within the production zone (implying insignificant fluid flow).

An explanation for the apparent low permeability of the valley fill near the active fault comes from the development of a new facies model for Basin and Range systems (Blackwell and Kelley, 1994). In this model (Leeder and Gawthrope, 1987) the active side of the valley, i.e. the one where the active normal faulting occurs, is the lowest part of the valley. Consequently the playa lake with its fine grained deposits is displaced toward the side of the valley that is actively subsiding instead of being centered in the basin and flanked on either side by alluvial fan material. When faulting slows down, alluvial fans build up the edges of the valley and push the playa toward the center of the valley. In Dixie Valley this effect is very clear. For example near the site of the 45-14 well the playa is within a few hundred meters of the topographic break while on the other side of the valley the bedrock outcrop is several kilometers from the edge of the playa. This explanation of the thermal and drilling data leaves the seismic observations unexplained, however.

Secondly, in 1993/1994 drilling by DVPP in sections 23 and 14 of T24N, R36E (Figure 18) demonstrated that the $54^{\circ}$ model for the geothermal system could not be extended to the south of the Oxbow field. The two wells covered the possible extent of a less than $85^{\circ}$ southeast-dipping rangebounding fault with no evidence of a fault intersection in either well although both wells had maximum temperatures higher than any of the producing wells in the Oxbow field. The 36-14 well intersected productive fractures with $285^{\circ} \mathrm{C}\left(545^{\circ} \mathrm{F}\right)$ fluid at a position that constrains the dip of the fluid-bearing fractures to have a dip of 85 to $90^{\circ}$ if the thermal source is the range front fault. 

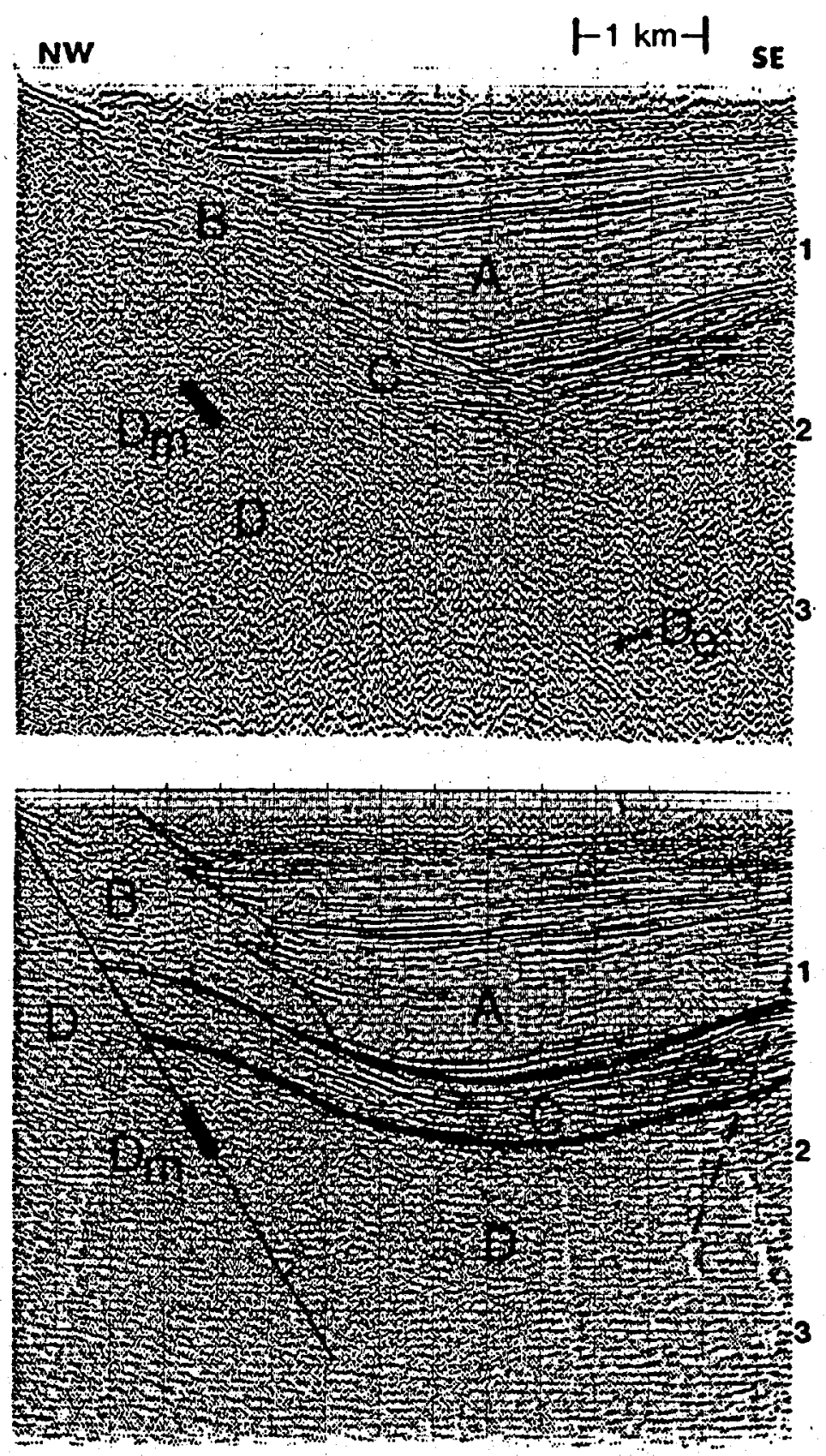

Figure 19. Seismic line SRC-3 as interpreted by Okaya and Thompson, (1985). Depth in seconds (two-way travel time). $\mathrm{A}$ is valley fill, $\mathrm{B}$ is alluvial fan material, and $\mathrm{D}$ is bedrock.

Thirdly, shallow drilling between the producing wells and the range front since 1994 has illustrated the existence of more upflow and shallow leakage of hot fluid into the valley fill then had been previously recognized (see Allis et al., 1999). Areas of high temperature leakage and areas of lateral flow into the valley have been recognized. Mineralization has been found to be associated with one part of the leakage (Johnson et al., 2000). One of the shallow wells was utilized for injection starting in August, 
1999. There has been significant pressure support to the reservoir from the injection, but no tracer breakthrough over a 9 month period. Therefore, a direct connection to the reservoir down a single fault plane is unlikely.

Although the Oxbow wells are about the same distance from the range front, they do not imply a uniform flow along the fault. The reservoir production model, based on well interference data, shows a series of heterogeneous connections within the "reservoir" (Benoit, 1999, Figure 9). There are lowpermeability wells north, between, and south of the two groups of producing wells. However, two of the wells in section 5 (25-5 and 45-5) are used as injectors as are some of the wells south of section 7. Connection of wells 25-5 and 45-5 to the reservoir in section 7 (but not section 33) has been proved by tracer testing (Rose et al., 1998). The wells in sections $21,22,23$, and 14 and further south have artesian reservoir pressures despite the large drawdowns in the Oxbow field.

\subsection{GRAVITY INTERPRETATION}

The results of the gravity survey give a framework for understanding some of the complexity of the seismic reflection sections. The main displacement of the valley fill is along a fault system that is within the valley, while the topographic displacement is taken up along the range bounding fault (along the contact of the range and the valley) (Figure 20). The broken up area on the section shown in Figure 19 (Okaya and Thompson, 1985) is not valley fill at all, rather it is the expression of shallow fill on top of the basement wedge between the range offsetting fault and the valley offsetting piedmont fault. This inability to clearly image the structure in the vicinity of the fault zone is a common problem with all of the seismic sections. Recent reprocessing of several seismic lines using migration techniques supports the idea that basement underlies the edge of the valley (Honjas et al., 1998) as suggested by the gravity interpretation. The gravity together with the drilling data suggest that there are complex variations along the strike of the range/valley contact, and require that it be a series of faults rather than a single structure. For example, there are piedmont faults along most of the contact that take up much of the displacement between the range-valley topographic contact and the valley bottom similar to those documented at the southern end of Dixie Valley (Bell and Katzer, 1987, Figure 3). However, most of the topographic relief is due to a series of faults at the contact of the range and valley that in general have relatively little displacement of the valley fill. Finally the extension process is evident in the ubiquitous occurrence of antithetic faults forming grabens on the hanging wall (downthrown side) of the major faults. The gravity data do not resolve these smaller scale structures, but the drilling (Benoit, 1999) and the migrated seismic sections (Honjas et al., 1998; Simtech, 1994) do.

\subsection{NORMAL FAULT MODEL FOR BASIN AND RANGE GEOTHERMAL SYTEMS}

Some implications of the geometry of the normal fault system for geothermal exploration are illustrated in Figure 21. Based on this model the fault system along the range front has several targets for drilling, not just one range-front fault. For example it implies that the Senator fumaroles are not 


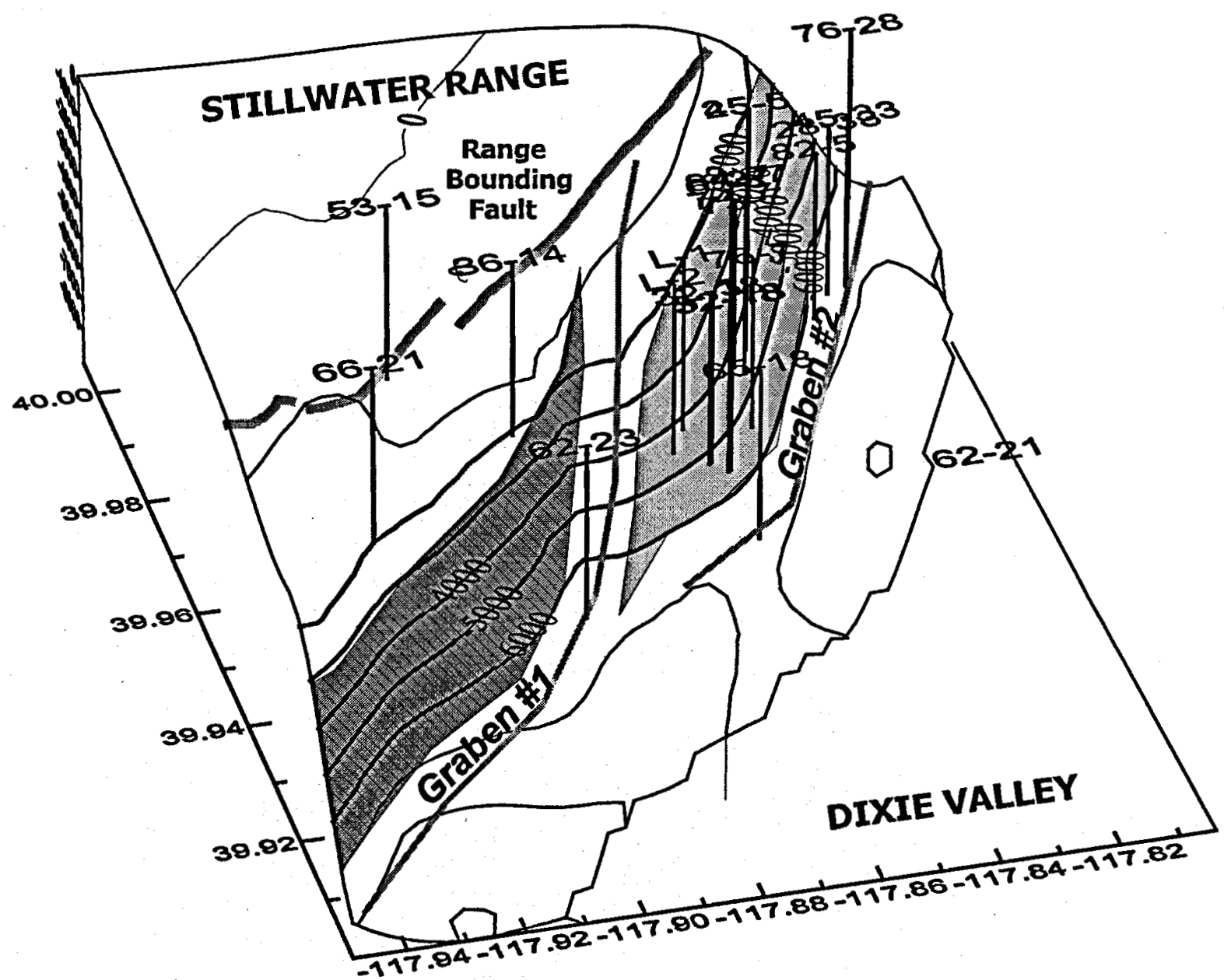

Figure 20. Perspective diagram of the range/valley contact with the valley fill removed. The depths have been calculated and contoured based on a density contrast of $-0.5 \mathrm{gm} / \mathrm{cm}^{3}$ from profiles shown in Blackwell et al. (1999b). Well position is at the bottom of the line connecting to the well identification number. Grabens inferred with help of the seismic data

directly updip on the production zone in section 33 since in this model active through flow on the piedmont faults would be discharged into the valley fill. The discharge for the zone feeding the wells in section 7 must happen into the valley fill if there was any natural flow before production began. Pressure differences between the cold water in the basin and the hot geothermal fluids mean that there is probably little upflow on these faults. Similarly, the fumaroles in sections 14 and 10 are not updip on the main valley (piedmont) fault because its subcrop intercept at the base of the valley fill is several hundred meters into the valley. 


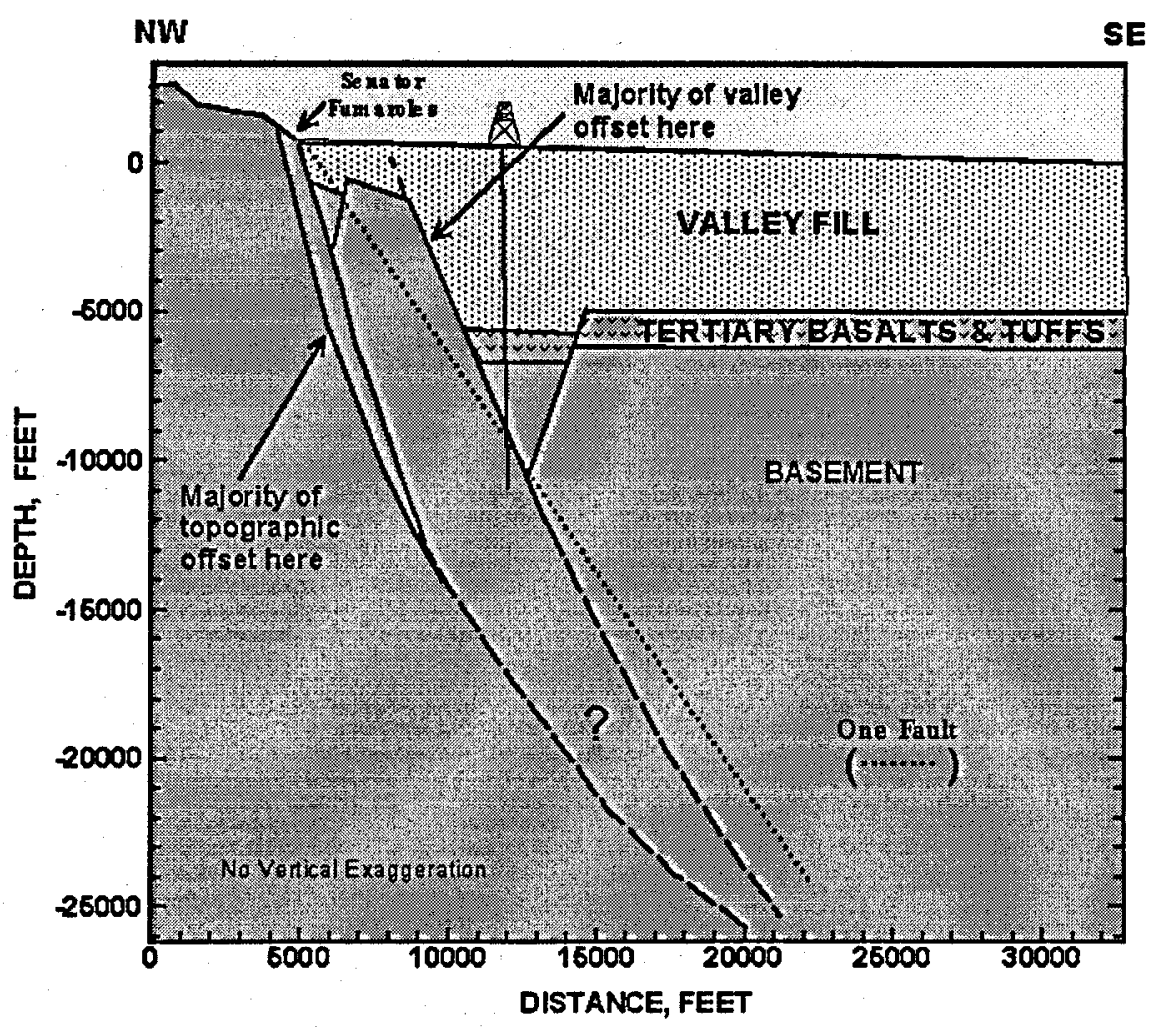

Figure 21. Fault splay model of the Dixie Valley/Stillwater Range bounding structure compared to the single fault model.

The structure of the fault zone deduced here is by no means novel. For example, the structure of the fault zone in the area of the 1954 earthquake about $30 \mathrm{~km}$ to the south of the area described here is shown in Figure 22 based on studies of Bell and Katzer (1987). This section shows the features illustrated in Figure 21, the range bounding fault, the piedmont fault, and the antithetic graben. Thus, the features seen in the area of the geothermal field are similar to those to the south.

The pattern shown in Figure 21 is modified in three dimensions due to the change in strike of many of the faults. The major (piedmont) fault associated with the south end of the Oxbow field results from a bifurcation of a single range bounding fault in the area north of the Senator fumaroles. This piedmont fault dies out in the vicinity of the wells in section $18 \mathrm{~T} 24 \mathrm{~S}, \mathrm{R37E}$, southwest of the producing wells in section 7. Its displacement is taken up by the piedmont fault extending to the south in the DVPP lease area. 


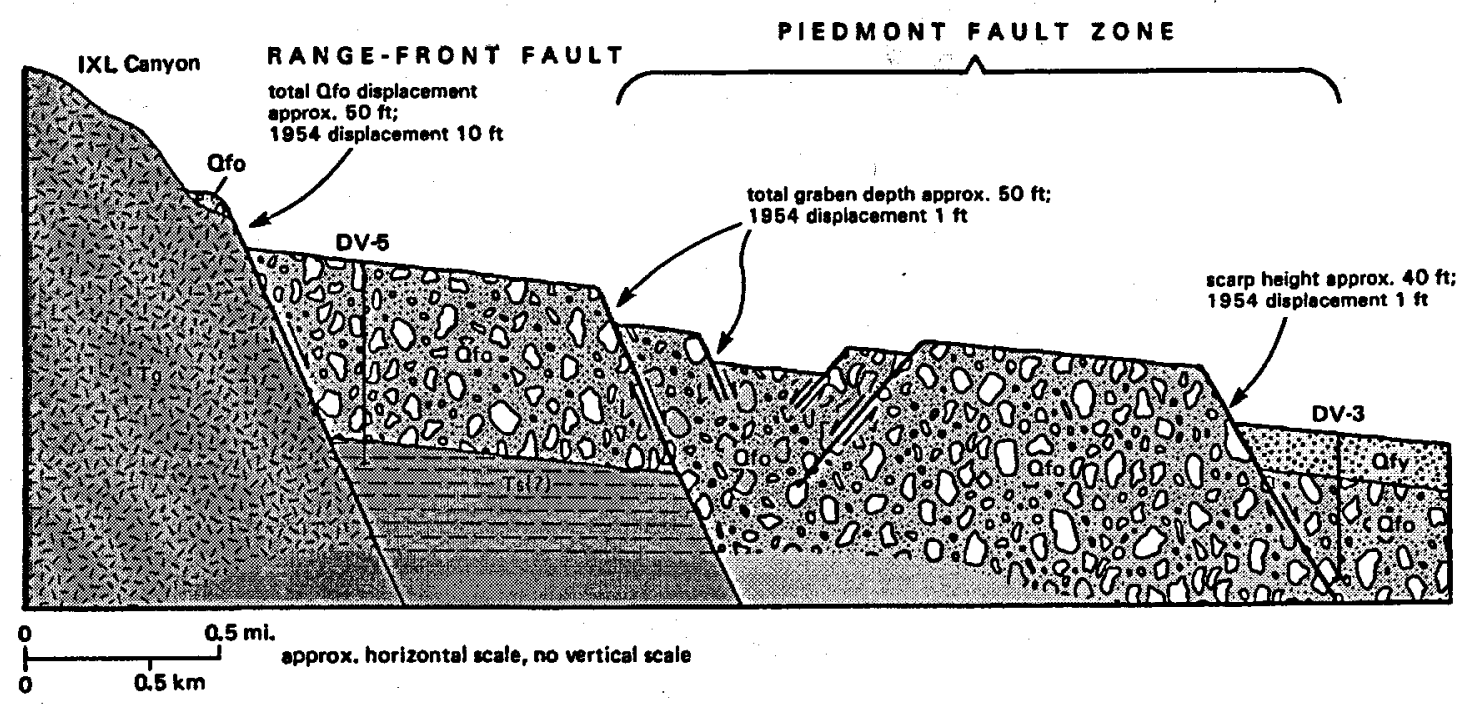

Figure 22. Schematic composite cross section of the IXL and East Job Canyons range-front and piedmont faults. Tg: Tertiary granite and granodiorite; Ts: Tertiary sediments; Qfo: old alluvial-fan deposits; Qfy: young alluvial fan deposits (from Bell and Katzer, 1987, Figure 37).

There is a fault plexus in the region of sections $10,11,14$, and 15 where at least two normal faults mapped within the Stillwater Range (Plank, 1998), the range bounding fault, and two piedmont faults interact. This area is a source of upwelling fluid that is hotter than the fluid in the Oxbow producing area and so is an area of potential development. The complex geometry of the faults can explain the results of the drilling in the DVPP lease at wells 62A-23 and 36-14 (Figure 18). There is also additional complexity introduced by the existence of major cross structures from an earlier Basin and Range episode (Parry et al., 1991). The strike of these earlier faults is N-S and in the area just south of the area of Figure 18; they can be demonstrated to have controlled the surface expression of the present range bounding normal fault.

Considerable controversy exists about the overall dip of the Dixie Valley normal fault system. In contrast to the steep dips (greater than $45^{\circ}$ ) assumed by most investigators, e.g. Okaya and Thompson (1985), in the past a model of shallow dipping normal faults has become popular. For example Plank et al. (1999) and Louie et al. (1999) argue that the dip of the Dixie Valley normal fault system is low and that the piedmont step is actually a normal fault ramp structure. However, one of the discoveries of detailed mapping is that there are several steep normal faults parallel to the range front in the area of the Oxbow field (Plank, 1998). So that evidence seems to point to the range bounding fault being steep (greater than $45^{\circ}$ ). The strongest evidence for the dip at depth comes from the thermal data. Significant over turns have not been observed below the producing zones in any of the wells ( 2.5 to 3 km deep in the Oxbow field). If the structures controlling the geothermal flow were shallow in dip, such overturns might be expected (Wisian, 1999). The temperature in both of the DVPP wells exceeds the maximum measured in the Oxbow field and the position of the highest temperature (in the 36-14 
well) is not far from the range front and in both wells is at a depth of about $3.5 \mathrm{~km}$. Thus, there is no doubt that some of the fractures that feed the geothermal system are steep (indeed they may be nearly vertical, 85 to $90^{\circ}$ in places) within the upper $3.5 \mathrm{~km}$ of the crust (Figure 21).

Exploration and Production Implications Development of the geothermal resources in Dixie Valley has been based on the model that a conjunction of a normal fault and the permeable geologic units along the fault are required for production. Favorable units are ones that are brittle and keep open fractures such as the Humboldt lopolith units in contrast to other units such as the Triassic shales that do not appear to support open fractures even along the fault (Benoit, 1999). Recently it has been pointed out that the orientation of structures with respect to the regional stress field may play an important part in the permeability distribution (Hickman et al., 1998; Barton et al., 1998).

The model shown in Figure 21 has many possible fault strands all along the valley/range contact and within both the valley and the range. The deep drilling, temperature gradient exploration, and thermal manifestations together indicate that most, if not all, of these strands have high-temperature fluid flow along them in some places in the greater Dixie Valley geothermal system. The resulting complexity of the system offers challenges to the exploration and drilling, but it also offers production opportunities and potential reservoir volumes that were not expected based on the single fault model. The fact that none of the deep wells has a definite temperature rollover is consistent with the fact that the reservoir is much larger in volume than a single strand of a Basin and Range normal fault. Thus, within the Oxbow field there are a number of potential reservoir structures that have not been tested by drilling. These may already interact with the producing structures via cross faults and/or fracturing, or they may only interact at some unknown depth where all of the strands intersect. In addition there are clearly multiple potential fluid bearing structures in the DVPP area as well, some of which are carrying fluid at temperatures of at least $285^{\circ} \mathrm{C}$. These results and the extensive areas of thermal manifestations elsewhere in Dixie Valley are taken to imply that the geothermal resource may be much more extensive than indicated by the area of present development. 


\subsection{DISCUSSION AND ACKNOWLEDGEMENTS}

\subsection{DISCUSSION}

The several activities related to geothermal resources in the western United States described in this report were designed to increase the effectiveness and accuracy of exploration and evaluation of geothermal systems in the western U.S. both on a regional and individual system basis. As one activity a database of geothermal site-specific thermal gradient and heat flow results from individual exploration wells in the western U.S. has been assembled. Extensive temperature gradient and heat flow exploration data from the active exploration of the 1970's and 1980's were collected, compiled, and synthesized, emphasizing previously unavailable company data. At the completion of the project the database included over 5300 well sites. Most of these well locations are part of the 133 groups that have been designated as specific geothermal areas. Some of these have not previously been identified in the literature as geothermal anomaly areas before. Another approximately 500 wells are essentially single point sites and may represent potential unexplored geothermal systems. The database and results are available on the world wide web at http://www.smu.edu/ geothermal so that the results may be immediately used by industry. Examples of the use and applications of the database are described.

One of the more unusual, important geothermal setting in the western U.S. is the Basin and Range province. Unlike the common association of geothermal systems in volcanic areas with magmatism, geothermal systems in the Basin and Range are associated with deep circulation of water along fault and fracture systems in this extensional setting. Magmatic activity plays little part in these systems. The controls on the thermal structure in these systems are not as well understood as in magma systems. So a second aspect of the project focused on the characteristics of the Basin and Range province of the United States, realizing the results apply to extensional settings in general. Understanding these systems is important because most potentially useful geothermal systems remaining in the western U.S., even outside of the Basin and Range, are of the extensional type. Numerical models are used to establish basic qualitative relationships between structure, heat input, and permeability distribution, and the resulting geothermal system. A series of steady state, twodimensional numerical models evaluate the effect of permeability and structural variations on an idealized, generic Basin and Range geothermal system and the results were described.

We used numerical modeling to demonstrate that an extensional geothermal system only exists in a relatively narrow range of bulk permeability $\left(10^{-15}-10^{-16} \mathrm{~m}^{2}\right)$. Outside of this window maximum (anomalous) temperature differences in the shallow sub-surface decrease rapidly. The presence of a relatively permeable upflow path (provided by geologically recent faulting for example) is a requirement for system development. Chemical self-sealing of upflow paths does not significantly effect the flow system as long as a central flow path is still available. While topography gives an extra, early "kick" to convective circulation, it is not a requirement for geothermal system development. A permeable fault in one valley can also induce cross-range flow from adjacent valleys if there are no equally good upflow paths in the adjacent valleys. When bulk permeability is high enough, additional deep circulation cells develop in adjacent valleys diverting heat and fluid from the 
fault and consequently reducing temperatures in the fault. Thus the density of geothermal systems is closely related to over all crustal permeability distribution.

The density of high temperature $\left(>150^{\circ} \mathrm{C}\right)$, extensional geothermal systems is predicted to increase rapidly with regional heat flow. The fit of the curve suggests that sampling of known geothermal systems is unbiased to any significant degree in all but the highest heat flow regions. Reservoir temperatures (anomalous temperatures) of known geothermal systems are lower in areas with heat flow less than $80 \mathrm{~mW} / \mathrm{m}^{2}$ and generally uninteresting for power generation. For typical values of thermal conductivity, and assuming reservoir temperature equals geochemical system temperature, the depth of circulation of most Basin and Range systems is less than $5 \mathrm{~km}$. Taken together, the data suggest that there is little value to exploration for electric grade resources associated with extensional geothermal systems in areas with a background heat flow of less then $80 \mathrm{~mW} / \mathrm{m}^{2}$.

Finally, we have published new information documenting that the Dixie Valley geothermal system, with temperatures up to $248^{\circ} \mathrm{C}$ in the Oxbow field and up to $285^{\circ} \mathrm{C}$ in the Dixie Valley Power Partners leasehold, is the hottest extensional (non-magmatic) geothermal system known in the Basin and Range province. Water circulation to $8-10 \mathrm{~km}$ is probable. Clearly, in areas of active faulting very high temperatures are possible even in the absence of magmatic systems. Therefore there may be more geothermal potential associated with nonmagmatic systems in the western U.S. then previously recognized. We have also shown that, based on new information and interpretations, including reprocessed seismic lines, gravity studies, and temperature-depth results from shallow and deep wells, the structure is complicated. There is a complex zone of fracturing that is the geothermal reservoir rather than a simple fault structure along the east side of the Stillwater Range. In addition to the fault causing the topographic offset, piedmont (within the valley) faults accommodate most of the displacement between the range-valley topographic contact and the bottom of the valley fill. Splays and/or relay ramps are also present. This structure complicates development drilling, but suggests that additional targets for exploration may be present and vastly increases the potential size of the geothermal reservoir associated with this extensional system.

\subsection{ACKNOWLEDGEMENTS}

In addition to the support of USDOE, some aspects of this project were partially supported by other funding sources. Part of this report is excerpted from the Wisian's Ph.D. dissertation (Wisian, 1999). That dissertation was supported in part by SMU and by the Albritton and Champlin awards from the Institute for the Study of Earth and Man, SMU. The field part of the gravity study of Dixie Valley was supported by Oxbow Geothermal Corp. and Dixie Valley Power Partners. The drilling and thermal data collection in the DVPP area of the Dixie Valley geothermal system was supported by DVPP and the results described here are with their permission. 


\subsection{REFERENCES CITED}

AMAX, Inc., 1980, McCoy, Nevada, 17 wells: lithologic logs and temperature depth data, UURI Open-file Rept. NV/MC/AMÁX-1.

AMAX, Inc., 1981a, Temperature depth logs of McCoy, Nevada, Wells 66-8 and 14-7, UURI Openfile Rept. NV/MC/AMAX-13.

AMAX, Inc., 1981b, McCoy, Nevada, Well 25-9 lithologic log and temperature depth data, UURI Open-file Rept NV/MC/AMAX-12.

AMAX, Inc., 1981c, McCoy, Nevada, Well 864-81 lithologic log and temperature depth data, UURI Open-file Rept. NV/MC/AMAX-101.

Allis, R.G., Stuart D. Johnson, Gregory D. Nash, and Dick Benoit, 1999, Geothermal Resources Council Trans., 23, 493-498.

Anderson, M.P., and W.W. Woessner, 1992, Applied Groundwater Modeling, Academic Press, London, $381 \mathrm{pp}$.

Barton, C. A., S. Hickman, R. Morin, M. D. Zoback, and D. Benoit, 1998, Reservoir scale fracture permeability in the Dixie Valley, Nevada, geothermal field, Twenty-third Workshop on Geothermal Reservoir Engineering, Stanford University, January 26-28, 1998.

Bell, J.W., and T. Katzer, 1987, Surficial geology, hydrology and late Quaternary tectonics of the IXI Canyon Area, Nevada, Nevada Bureau of Mines and Geology Bulletin, 102, 52 pp.

Benoit, D., 1999, A review of various conceptual models of the Dixie Valley, Nevada geothermal field, Geothermal Resources Council Trans., 23, 505-511.

Blackwell, D.D., and S. Kelley, 1994, Implications of facies models on geothermal systems in the Basin and Range Province, Geothermal Resources Council Trans., 18, 3-9.

Blackwell, D.D., and J.L. Steele, editors, 1992, DNAG geothermal map of North America, 1:5,000,000, 4 sheets, Geol. Soc. Amer., Boulder, Co.

Blackwell, D.D., and K.W. Wisian, 1997, Gravity analysis of Dixie Valley, Nevada geothermal system, unpublished draft report to Oxbow Geothermal and Caithness Corp., 25 pp.

Blackwell, D.D., B. Golan, and D. Benoit, 2000, Thermal characteristics of the Dixie Valley geothermal system, submitted to WGC2000.

Blackwell, D.D., J.L. Steele, and L.S. Carter, 1991, Heat flow patterns of the North American Continent; A discussion of the geothermal map of North America, p. 423-437, in Neotectonics of North America, ed. D.B. Slemmons, E.R., Engdahl, M.D. Zoback, and D.D. Blackwell, Geol. Soc. Am. Decade of North Am. Geol., Decade Map V. 1, 498 pp. 
Blackwell, D.D., J.L. Steele, and L.S. Carter, 1989, Heat flow database for the U. S., in Geophysics of North America CD-ROM, ed. A.M. Hittleman, J.O. Kinsfather, and H. Meyers, NOAA, Natl. Geophys. Data Center.

Blackwell, D.D., J.L. Steele, and K.W. Wisian, 1994, Results of geothermal resource evaluation for the eastern United States, Geothermal Resources Council Trans., 18, 161-164.

Blackwell, D.D., K.W. Wisian, and Maria Richards, 1996, Geothermal resources of the United States based on heat flow and gradient information, Final Report DOE contract C91-103450, 75 pp.

Blackwell, D.D., K.W. Wisian, and J.L. Steele, 1995, Geothermal regime in the central and eastern United States east of the Rocky Mountains, pp. 649-653, in Proc. World Geothermal Cong. 1995, ed. E. Barbier, G. Frye, E. Iglesias, and G. Palmason, V. 1, 665 pp.

Blackwell, D.D., M. Richards, K.W. Wisian, and J.L. Steele, 1999, System specific geothermal gradient/heat flow database for the western United States, Geothermal. Res. Council Trans., $23,461-466$.

Blackwell, D.D., K.W. Wisian, D. Benoit, and B. Golan, 1999, Structure of the Dixie Valley geothermal system, a "typical" Basin Range geothermal system, from gravity and thermal data, Geothermal Resources Council Trans., 23, 525-521.

Caskey, S.J., S.G. Wesnousky, P. Zhang, and D.B. Slemmons, 1996, Surface faulting of the 1954 Fairview Peak (Ms 7.2) and Dixie Valley (Ms 6.8) earthquakes, central Nevada, Bull. Seismol. Soc. Amer., 86, 761-787.

Forster, C., and L. Smith, 1988a, Groundwater Flow Systems in Mountainous Terrain 1. Numerical Modeling Technique, Water Resour. Res., 24, 999-1010.

Forster, C., and L. Smith, 1988b, Groundwater Flow Systems in Mountainous Terrain 2. Controlling Factors, Water Resour. Res., 24, 1011-1023.

Forster, C., and L. Smith, 1989, The Influence of Groundwater Flow on Thermal Regimes in Mountainous Terrain: A Model Study, J. Geophys. Res., 94, 9439-9451.

Fournier, R.O., 1990, The Interpretation of Na-K-MG Relations in Geothermal Waters, Geothermal Res. Council Trans., 14, 1421-1425.

Garside, L.J., 1997, Nevada geothermal gradient-hole database, Nevada Bureau of Mines and Geology. CD-ROM prepared under INEL Contract NO. C85-110656-005.

Garside, L.J., and J.H. Schilling, 1979, Thermal Waters of Nevada, Nevada Bureau of Mines and Geology Bulletin 91, 163 pp.

Gass, T.E., 1982, Geothermal heat pumps, Geothermal Resources Council Bulletin, 11, 3-8. 
Hickman, S. M. Zoback, and R. Benoit, 1998, Tectonic controls on reservoir permeability in the Dixie Valley, Nevada geothermal field, Proceedings, Twenty-third Workshop on Geothermal Reservoir Engineering, Stanford University, January 26-28, 6 pp.

Honjas, W., S. K. Pullammanappallil, J. R. Unruh, and G. L. Plank, 1998, Effectiveness of simulated annealing velocity modeling and Kirchoff migration for imaging laterally complex geologic environments within the Dixie Valley geothermal field, Nevada, Unpublished paper presented at the Geothermal Resources Council 1998 Annual Meeting.

Johnson, S.D., J.B. Hulen, F. Goff, and C Janik, 2000, An Integrated study of precious metal deposition and petroleum generation related to the Dixie Valley geothermal system, Nevada, USA, Abstract submitted to the World Geothermal Congress 2000.

Leeder, M. R., and R. L. Gawthrope, 1987, Sedimentary models for the extension tilt-block/half graben basins, pp. 139-152, in M. P. Coward and P. L. Hancock, eds., Continental Extensional Tectonics, Geol. Soc. London Spec. Pub. 28.

Lopez, D.L., and L. Smith, 1995, Fluid flow in fault zones: Analysis of the interplay of convective circulation and topographically driven groundwater flow, Water Resour. Res., 31, 1489-1503.

Lopez, D.L., and L. Smith, 1996, Fluid flow in fault zones: Influence of hydraulic anisotropy and heterogeneity on the fluid flow and heat transfer regime, Water Resour. Res., 32, 3227-3235.

Lopez, D.L., L. Smith, and M.L. Sorey, 1994, Modeling Fluid Flow and Heat Transfer at Basin and Range Faults: Preliminary Results for Leach Hot Springs, Nevada, Geothermal Resources Council Transactions, 18, 11-16.

Louie, J. N., S. J. Caskey, and S. G. Wesnousky, 1999, Preliminary results of a geophysical test of lowangle dip on the seismogenis Dixie Valley fault, Nevada, http://www.seismo.unr.edu/ftp/louie/dixie/prelim.html, 9 pp.

Mariner, R.H., J.B. Rapp, L.M. Willey, and T.S. Presser, 1974, The chemical composition and estimated minimum thermal reservoir temperatures of the principal hot springs of northern and central Nevada, USGS Open-File Report 74-1066, 32 pp.

Mariner, R.H., T.S. Presser, and W.C. Evans, 1983, Geochemistry of active geothermal systems in the northern Basin and Range province, Geothermal Res. Council Special Report, 13, 95-119.

Moridis, G., and K. Pruess, 1995, Flow and Transport Simulations Using T2CG1, A Package of Conjugate Gradient Solvers for the TOUGH2 Family of Codes, LBL -36235, Lawrence Berkeley Laboratory, 118 pp.

Muffler, L.J.P., ed, 1979, Assessment of Geothermal Resources of the United States--1978, U. S. Geol. Surv. Circ. 790, 163 pp.

Nicholson, K., 1993, Geothermal Fluids, 263 pp., Springer-Verlag, New York. 
Okaya, D. A., and G. A. Thompson, 1985, Geometry of Cenozoic extensional faulting: Dixie Valley, Nevada, Tectonics, 4, 107-125.

Olson, H. J., F. Dellechaie, H. D. Pilkington, and A. L. Lange, 1979, The McCoy geothermal prospect, status report of a possible new discovery in Churchill and Lander Counties, Nevada, Geothermal Resources Council Trans., 3, 515-518.

Parry, W. T., D. Hedderly-Smith, and R. L. Bruhn, 1991, Fluid inclusions and hydrothermal alteration on the Dixie Valley fault, Nevada, J. Geophys. Res., 96, 19,733-19,748.

Parry, W.T., P.N. Wilson, and R.L. Bruhn, 1988, Pore fluid chemistry and chemical reactions on the Wasatch normal fault, Utah, Geochim. Cosmochim. Acta, 52, 2053-2063.

Pilkington, H.D., 1982, McCoy Area, Nevada, Geothermal reservoir assessment case history, Northern Basin and Range, Final report DOE/ET/27010-1, under contract DE-AC08ET27010, AMAX Exploration, Inc., $68 \mathrm{pp}$.

Plank, G.R., 1998, Structure, stratigraphy, and tectonics of a part of the Stillwater escarpment and implications for the Dixie Valley geothermal system, M. S. Thesis, University of Nevada, Reno, $153 \mathrm{pp}$.

Plank, G., R. Schweickert, D. Benoit, and A. Simmons, 1999, Influence of fault surface geometry on the location of the Dixie Valley geothermal area, Dixie Valley, Nevada, Paper presented at the Twenty-fourth Workshop on Geothermal Reservoir Engineering, Stanford University, January 25-27, 1999.

Pruess, K., 1987, TOUGH User's Guide, LBL-20700, Lawrence Berkeley Laboratory, Berkeley, California, $78 \mathrm{pp}$.

Pruess, K., 1991, TOUGH2-A General-Purpose Numerical Simulator for Multiphase Fluid and Heat Flow, LBL-29400, Lawrence Berkeley Laboratory, Berkeley, California, 102 pp.

Pruess, K., S. Finsterle, G. Moridis, C. Oldenburg, and Y. Wu, 1997, General-Purpose Reservoir Simulators: the TOUGH2 Family, Geothermal Resources Council Bulletin, 26:2, 53-57.

Raines, Gary L. Don L. Sawatzky, and Katherine A. Connors, 1996, U.S. Geological Survey Digital Data Series DDS-041, Great Basin Geoscience Database.

Reed, M.J., ed., 1983, Assessment of low-temperature geothermal resources of the United States-1982, U. S. Geol. Surv. Circ. 892, 73 pp.

Rogers, A.M., S.C. Harmsen, E.J. Corbett, K. Priestley, and D. dePolo, 1991, The seismicity of Nevada and some adjacent parts of the Great Basin, pp. 423-436, in Neotectonics of North America, eds. D. B. Slemmons, E. R. Engdahl, M. D. Zoback, and D. D. Blackwell, Geol. Society Am., Decade Map Volume 1.

Rose, P.E., W.R. Benoit, and M.C. Adams, 1998, Tracer testing at Dixie Valley, Nevada, using Pyrene Tetrasulfonate, Amino G and Fluorescein, Geothermal Resources Council Trans., 22, 583-587. 
Saltus, R. W., 1988, Regional, residual, and derivative gravity maps of Nevada, Nev. Bur. Mines and Geol. Map 94B, 1:1,000,000.

Simtech, 1994, Interpretation of migrated seismic sections in Dixie Valley, Nevada, Unpublished report for Dixie Valley Power Partners., Simtech Consulting Services Inc.

Sorey, M.L., and F.H. Olmsted, 1994, The Hydrothermal System Associated with Leach Hot Springs in Southern Grass Valley, Nevada, Geothermal Resources Council Transactions, 18, 31-36.

Speed, R., 1976, Geology of the Humboldt lopolith \& vicinity, Geol. Soc. Amer. Map MC-14, Boulder, Colo.

Stewart, John and Edwin McKee, 1977, Geology and mineral deposits of Lander County, Nevada, Nevada Bureau of Mines and Geology Bulletin 88, 106 pp.

Straus, J.M., and G. Schubert, 1977, Thermal Convection of Water in a Porous Medium: Effects of Temperature- and Pressure-Dependent Thermodynamic and Transport Properties, J. Geophys. Res., 82:2, 325-333.

UURI, 1981, Seismic sections in Dixie Valley, Nevada, University of Utah Research Institute Open-file Report.

Vikre, P.G., 1989, Fluid-mineral relations in the Comstock lode, Econ. Geol., 84, 1574-1613.

Welch, A.H., M.L. Sorey, and F.H. Olmsted, 1981, The Hydrothermal System in Southern Grass Valley, Pershing County, Nevada, USGS Open File Report, 81-915, 193 pp.

Willden, Ronald and Robert Speed, 1974, Geology and mineral deposits of Churchill County, Nevada, Nevada Bureau of Mines and Geology Bulletin 83, 95 pp.

Wisian, K.W., 2000, Insights into extensional geothermal systems from numerical modeling, submitted to WGC2000.

Wisian, K.W., 1999, Numerical modeling of Basin and Range geothermal systems and other geophysical studies, PhD Dissertation, Southern Methodist University, $165 \mathrm{pp}$.

Wisian, K.W., D.D. Blackwell, and M. Richards, 1999, Heat flow in the western U.S. and extensional geothermal systems, Proceedings, 24th Workshop on Geothermal Reservoir Engineering, Stanford University, Stanford, Ca., January 25-27, v. 24, 219-226.

Wright, P.M., 1991, Exploration for new hydrothermal resources for electrical power generation in the 48 contiguous United States, Geothermal Resources Council Transactions, 15, 217-228.

Yeamans, F., 1983, Basin and Range Geothermal Hydrology: an Empirical Approach, in Geothermal Resources Council Special Report, 13, 159-175. 